\title{
Methodological Quality Assessment with the AGREE II Scale and a Comparison of European and American Guidelines for the Treatment of Lyme Borreliosis: A Systematic Review
}

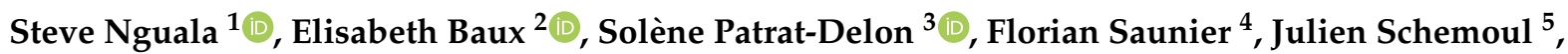 \\ Pierre Tattevin ${ }^{3}$, Céline Cazorla ${ }^{4}$, Carole Eldin ${ }^{6,7}$, Kevin Bouiller ${ }^{8,9}$ (D) and Alice Raffetin ${ }^{1,10, *(\mathbb{D})}$
}

1 Department of Infectious Diseases, Tick-Borne Diseases Reference Center, North Region, Hospital of Villeneuve-Saint Georges, 40 Allée de la Source, 94190 Villeneuve-Saint-Georges, France; steve.nguala@chiv.fr

2 Department of Infectious Diseases, Tick-Borne Diseases Reference Center, East Region, Hospitals of Brabois-University Hospital of Nancy, Rue du Morvan, 54500 Vandoeuvre Les Nancy, France; e.baux@chru-nancy.fr

3 Department of Infectious Diseases and ICU, Tick-Borne Diseases Reference Center, West Region, University Hospital of Rennes Pontchaillou, CHU Rennes Pontchaillou, 2 Rue Henri Le Guilloux, 35033 Rennes, France; solene.patrat-delon@chu-rennes.fr (S.P.-D.); pierre.tattevin@chu-rennes.fr (P.T.)

check for

updates

Citation: Nguala, S.; Baux, E.;

Patrat-Delon, S.; Saunier, F.;

Schemoul, J.; Tattevin, P.; Cazorla, C.;

Eldin, C.; Bouiller, K.; Raffetin, A.

Methodological Quality Assessment with the AGREE II Scale and a

Comparison of European and

American Guidelines for the

Treatment of Lyme Borreliosis: A Systematic Review. Pathogens 2021, 10, 972. https://doi.org/10.3390/ pathogens 10080972

Academic Editors: Benoît Jaulhac, Olivier Sparagano and

Roberto Paganelli

Received: 16 May 2021

Accepted: 28 July 2021

Published: 31 July 2021

Publisher's Note: MDPI stays neutral with regard to jurisdictional claims in published maps and institutional affiliations.

Copyright: () 2021 by the authors. Licensee MDPI, Basel, Switzerland. This article is an open access article distributed under the terms and conditions of the Creative Commons Attribution (CC BY) license (https:// creativecommons.org/licenses/by/ $4.0 /)$.
4 Department of Infectious Diseases, Tick-Borne Diseases Reference Center, Central Region, University Hospital of Saint-Etienne, Avenue Albert-Raimond, 42270 Saint-Priest-en-Jarez, France; florian.saunier2@etu.univ-st-etienne.fr (F.S.); celine.cazorla@chu-st-etienne.fr (C.C.)

5 Department of Rheumatology, Tick-Borne Diseases Reference Center, North Region, Hospital of Villeneuve-Saint Georges, 40 Allée de la Source, 94190 Villeneuve-Saint-Georges, France; julien.schemoul@chiv.fr

6 Tick-Borne Diseases Reference Center, South Region IHU-Méditerranée Infection, 13005 Marseille, France; carole.eldin@ap-hm.fr

7 IRD, AP-HM, SSA, VITROME, Aix Marseille University, 13005 Marseille, France

8 Department of Infectious Diseases, University Hospital of Besançon, 3 Boulevard Alexandre Fleming, 25000 Besançon, France; kbouiller@chu-besancon.fr

9 UMR CNRS 6249 Chrono-Environnement, University of Franche-Comte, 25000 Besancon, France

10 European Study Group for Lyme Borreliosis ESGBOR, ESCMID, Gerbergasse 14 3rd Floor, 4001 Basel, Switzerland

* Correspondence: alice.raffetin@chiv.fr; Tel.: +33-143-862-068

Abstract: Background: Most European and American countries recently updated their guidelines on Lyme borreliosis (LB). The aim of this study was to provide a comparative overview of existing guidelines on the treatment of LB in Europe and America and to assess the methodological quality of their elaboration. Methods: A systematic search was carried out in MEDLINE, Google Scholar, and the national databases of scientific societies from 2014 to 2020. Quality was assessed by two independent reviewers using the Appraisal of Guidelines for Research and Evaluation II (AGREE II) tool. Results: Twelve guidelines were included. The scores for the AGREE II domains (median \pm IQR) were: overall assessment $100 \pm 22$, scope and purpose $85 \pm 46$, stakeholder involvement $88 \pm 48$, rigour of development $67 \pm 35$, clarity of presentation $81 \pm 36$, applicability $73 \pm 52$ and editorial independence $79 \% \pm 54 \%$. Cohen's weighted kappa showed a high agreement $(\mathrm{K}=0.90,95 \% \mathrm{CI}$ 0.84-0.96). Guidelines were quite homogeneous regarding the recommended molecules (mostly doxycycline in the first intention and ceftriaxone in the second intention), their duration (10 to 28 days), and their dosage. The differences were due to the lack of well-conducted comparative trials. The International Lyme and Associated Diseases Society (ILADS) guidelines were the only ones to suggest longer antibiotics based on an expert consensus. Conclusion: European and American guidelines for the treatment of LB were quite homogeneous but based on moderate- to low-evidence studies. Well-conducted comparative trials are needed to assess the best molecules, the optimal duration and the most effective doses.

Keywords: Lyme borreliosis; treatment; guidelines; AGREE II 


\section{Introduction}

Lyme borreliosis (LB) is the most frequent vector-borne disease in Europe and the USA [1,2]. The number of cases in Europe has increased steadily over the last two decades. The incidence of LB varies from a country to another from $0.001 / 100,000$ to $464 / 100,000$, with an unweighted mean incidence rate of 56.3/100,000 persons per year ( 232,125 cases/year) [1]. LB is transmitted by ticks and caused by spirochetes of the Borrelia burgdorferi sensu lato complex. The most frequent clinical pictures in Europe are erythema migrans (EM) and Lyme neuroborreliosis (LNB), but it can also affect joints such as Lyme arthritis (LA), heart and eyes [3,4]. The diversity of the clinical manifestations in Europe is due to the larger genospecies of Borrelia burgdorferi sensu lato (B. afzelii, B. garinii, B. burgdorferi sensu stricto etc.) compared to those in the USA (B. burgdorferi sensu stricto) [3]. Microbiological diagnosis mainly relies on a two-tier serological test and PCR according to the stage of the disease and the anatomical site sample [5-8]. An antibiotic therapy among doxycycline or beta-lactamin (ceftriaxone or amoxicillin) or azithromycin is prescribed between 10 and 28 days, also according to the stage of the disease (early $<6$ months or late $>6$ months) and the clinical manifestation. For the early localized stage (EM), antibiotic duration varies from 10 to 21 days, and for the disseminated stages, it ranges from 14 to 28 days. Long-term antibiotics (more than three months) have not shown superiority in any randomized trials [9-13]. In vitro antibiotic resistance has not been observed [14-16]. Some subjective symptoms may exist at all the stages and may persist after a well-conducted antibiotic therapy. This is called the post-treatment Lyme disease syndrome (PTLDS). Antibiotics are usually not recommended for the latter because there is no scientific evidence for the persistence of an active Borrelia, in clinically relevant studies [7].

Most of the European guidelines for the diagnosis and management of LB have been updated recently. They are consistent for the clinical and microbiological diagnosis of LB [6], but there are disparities between the recommended molecules, their duration and their dosage.

The aim of this study was to provide a comparative overview of the existing guidelines on the treatment of LB in Europe and America and to assess the methodological quality of their elaboration.

\section{Results}

The search strategies identified four guidelines from MEDLINE [7,17-19], two from Google Scholar [20,21], one from the Haute Autorité de Santé (HAS) [22], one from the National Institute for Health and Care Excellence (NICE) [23], two from.

The Arbeitsgemeinschaft der Wissenschaftlichen Medizinischen Fachgesellschaften (AWMF) [24,25], one from the Belgian Antibiotic Policy Coordination Committee (BAPCOC) [26] and one from the International Lyme and Associated Diseases Society (ILADS) [27]. The remaining number of guidelines found in each database after removal of duplicates and then selected for further review and met the inclusion criteria are shown in Figure 1. Eleven guidelines were developed by official academic societies [7,17-26] and one by a non-official organisation, the ILADS, defined as a 'transdisciplinary medical association' of physicians and researchers working on Lyme and tick-borne diseases (Table 1) [27]. This association is not officially recognised by American authorities as an academic society. 


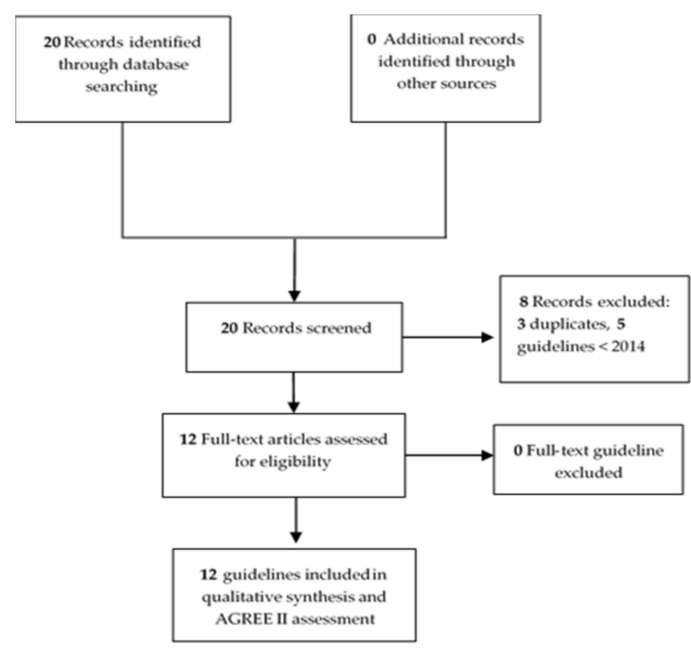

Figure 1. Study flow diagram.

Table 1. Characteristics of the 12 selected guidelines.

\begin{tabular}{|c|c|c|c|c|c|}
\hline & Guidelines & Country & Institution & Year & Type \\
\hline 1 & ILADS guidelines [27] & USA & ILADS & 2014 & $\begin{array}{l}\text { Evidence-based and } \\
\text { expert consensus }\end{array}$ \\
\hline 2 & Polish guidelines [20] & Polish & PSEID & 2015 & Evidence-based \\
\hline 3 & Swiss guidelines [17] & Swiss & SSID and SSN & 2016 & Evidence-based \\
\hline 4 & $\begin{array}{l}\text { Belgium guidelines [26] } \\
\text { German Dermatology }\end{array}$ & Belgium & BAPCOC & 2016 & Evidence-based \\
\hline 5 & $\begin{array}{l}\text { Society guidelines for } \\
\text { cutaneous LB [24] }\end{array}$ & Germany & AWMF & 2017 & Evidence-based \\
\hline 6 & ESGBOR guidelines [18] & Europe & ESGBOR & 2017 & Evidence-based \\
\hline 7 & $\begin{array}{c}\text { French High Health } \\
\text { Authority guidelines [22] }\end{array}$ & France & HAS & 2018 & Evidence-based \\
\hline 8 & NICE guidelines [23] & England & NICE & 2018 & Evidence-based \\
\hline 9 & $\begin{array}{l}\text { German Neurology Society } \\
\text { guidelines for LNB [25] }\end{array}$ & Germany & AWMF & 2019 & Evidence-based \\
\hline 10 & $\begin{array}{c}\text { French scientific societies } \\
\text { guidelines [7] }\end{array}$ & France & $\begin{array}{l}\text { French scientific } \\
\text { societies }\end{array}$ & 2019 & Evidence-based \\
\hline 11 & $\begin{array}{l}\text { Canadian guidelines, Prince } \\
\text { Edward Island [21] }\end{array}$ & Canada & $\begin{array}{l}\text { Department of } \\
\text { Health }\end{array}$ & 2019 & Evidence-based \\
\hline 12 & American guidelines [19] & USA & IDSA & 2020 & Evidence-based \\
\hline
\end{tabular}

ILADS = International Lyme and Associated Diseases Society; PSEID = the Polish Society of Epidemiology and Infectious diseases, SSID = Swiss Society of Infectious Disease, SSN = Swiss Society of Neurology; BAPCOC = Belgian Antibiotic Policy Coordination Committee; AWMF = The Arbeitsgemeinschaft der Wissenschaftlichen Medizinischen Fachgesellschaften; ESGBOR = European Study Group for Lyme Borreliosis; HAS = Haute Autorité de Santé, High Health Authority; NICE = National Institute for Health and Care Excellence; IDSA = Infectious Diseases Society of America.

\subsection{Methodological Quality Assessment (cf. Table 2)}

\subsubsection{Overall Assessment}

The overall quality of guidelines varied, but most of the methodological quality of guidelines was admissible. The overall quality was more than $50 \%$ in nine included guidelines [7,17-19,22-26], especially in five $[7,19,23-25]$ which scored $100 \%$. Two guidelines relied on the GRADE approach $[19,27]$, which is the highest quality standard. Six guidelines were rated according to AGREE II as 'recommended by reviewers' (score > 80\%) [7,17,19,23-25], three as 'recommended with modifications' (score between $50 \%$ and $80 \%$ ) $[18,22,26]$ and three as 'not recommended' (score $<50 \%$ ) $[20,21,27]$. Cohen's weighted kappa showed that appraisers reached a high agreement $(K=0.90,95 \%$ CI 0.84-0.96) (Table 2). 
Table 2. AGREE II domain scores for the 12 guidelines, after a blind evaluation by two appraisers.

\begin{tabular}{|c|c|c|c|c|c|c|c|c|}
\hline Guidelines & $\begin{array}{l}\text { Scope and } \\
\text { Purpose }\end{array}$ & $\begin{array}{l}\text { Stakeholder } \\
\text { Involvement }\end{array}$ & $\begin{array}{c}\text { Rigor of } \\
\text { Development }\end{array}$ & $\begin{array}{c}\text { Clarity of } \\
\text { Presentation }\end{array}$ & Applicability & $\begin{array}{c}\text { Editorial } \\
\text { Independence }\end{array}$ & $\begin{array}{c}\text { Overall } \\
\text { Assessment }\end{array}$ & Recommended \\
\hline ILADS [27] & $100 \%$ & $69 \%$ & $58 \%$ & $22 \%$ & $31 \%$ & $13 \%$ & $42 \%$ & $N$ \\
\hline PSEID [20] & $81 \%$ & $31 \%$ & $10 \%$ & $58 \%$ & $44 \%$ & $29 \%$ & $33 \%$ & $N$ \\
\hline BAPCOC [26] & $72 \%$ & $50 \%$ & $40 \%$ & $67 \%$ & $71 \%$ & $58 \%$ & $53 \%$ & $Y M$ \\
\hline AWMF [24] & $100 \%$ & $100 \%$ & $96 \%$ & $86 \%$ & $81 \%$ & $100 \%$ & $100 \%$ & $Y$ \\
\hline ESGBOR [18] & $75 \%$ & $58 \%$ & $66 \%$ & $42 \%$ & $44 \%$ & $79 \%$ & $50 \%$ & $Y M$ \\
\hline HAS [22] & $100 \%$ & $100 \%$ & $88 \%$ & $83 \%$ & $79 \%$ & $54 \%$ & $75 \%$ & $Y M$ \\
\hline AWMF [25] & $100 \%$ & $100 \%$ & $98 \%$ & $89 \%$ & $94 \%$ & $100 \%$ & $100 \%$ & $Y$ \\
\hline $\begin{array}{c}\text { French scientific } \\
\text { societies [7] }\end{array}$ & $100 \%$ & $100 \%$ & $99 \%$ & $87 \%$ & $92 \%$ & $100 \%$ & $100 \%$ & $Y$ \\
\hline Canada [21] & $64 \%$ & $36 \%$ & $17 \%$ & $39 \%$ & $85 \%$ & $42 \%$ & $25 \%$ & $N$ \\
\hline IDSA [19] & $100 \%$ & $100 \%$ & $100 \%$ & $63 \%$ & $94 \%$ & $96 \%$ & $100 \%$ & $Y$ \\
\hline Median $\pm \mathrm{IQR}$ & $100 \% \pm 22 \%$ & $85 \% \pm 46 \%$ & $88 \% \pm 48 \%$ & $67 \% \pm 35 \%$ & $81 \% \pm 36 \%$ & $73 \% \pm 52 \%$ & $79 \% \pm 54 \%$ & \\
\hline Cohen's kappa & - & - & - & - & - & - & $0.90(0.84-0.96)$ & \\
\hline
\end{tabular}

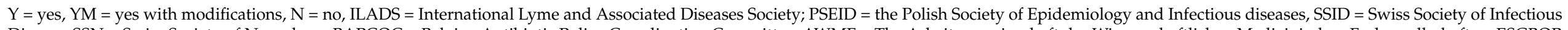

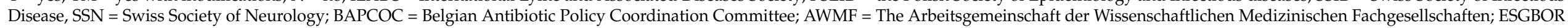

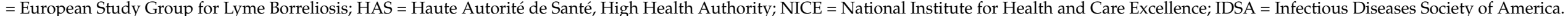




\subsubsection{Scope and Purpose}

Overall objectives were described in eleven guidelines [7,17-20,22-27], and specific health questions were described in eight $[7,17,19,22-25,27]$. The population to whom the guidelines were meant to apply were exactly described in ten [7,17-20,22-25,27].

\subsubsection{Stakeholder Involvement}

The domain stakeholder involvement was described to some degree. Seven guidelines provided their development group [7,19,22-25,27], seven attempted to find the views and preferences of the target population $[7,19,22-25,27]$, and nine clearly defined target users $[7,17-19,22-25,27]$.

\subsubsection{Rigour of Development}

Systematic methods to search for evidence were reported in nine guidelines [7,17-19,22-25,27]. Criteria for selecting evidence and method for formulating the recommendation were described in six guidelines $[7,19,22-25]$. Seven described the strengths and limitations $[7,17,19,22,24,25]$. Seven considered the health benefits, side effects and risks in formulating the recommendations $[7,17-19,22,24,25]$. Eight presented the link between recommendations and supporting evidence as reference to the respective evidence $[7,17-19,22-25]$. Seven were externally reviewed by experts before their publications $[7,19,22-26]$. Only one provided an updating procedure [22].

\subsubsection{Clarity of Presentation}

Nine guidelines had specific and unambiguous recommendations [7,17-19,22-26]. Nine provided different options for the management of conditions or health issues [7,17-19,22-26]. All guidelines identified key recommendations [7,17-27].

\subsubsection{Applicability}

Eleven guidelines described facilitators and barriers to applications [7,17-26]. All guidelines provided advice and/or tools on how recommendations can be put in practice to some degree [7,17-27]. Eight considered the potential resource implications of applying the recommendations $[7,17,19,21-25]$, and a further eight presented monitoring and/or auditing criteria, including patients' advice [7,17-19,22,23,25,26].

\subsubsection{Editorial Independence}

Editorial independence was evaluated by two parameters: "The views of the funding body have not influenced the content of the guideline" and "Competing interests of guideline development group members have been recorded and addressed". Eight guidelines explained that the views of the funding body had no influence on content $[7,17-19,23-26]$. Conflicts of interest were revealed in nine guidelines [7,17-19,22,24-26], but the mechanism of these conflicts' potential influence on recommendations was unclear.

\subsection{Comparison of Recommended LB Treatments}

2.2.1. Treatment of Skin Manifestations (cf. Table 3)

Erythema Migrans (EM)

Of the 12 guidelines, 2 did not recommend a specific treatment for EM because they dealt with LNB and PTLDS only [17,25] (Table 3). 
Table 3. Comparative table of the treatment recommended in the European and American guidelines for cutaneous LB.

\begin{tabular}{|c|c|c|c|c|c|c|}
\hline \multirow{2}{*}{ Guidelines } & \multicolumn{2}{|c|}{ Erythema Migrans } & \multicolumn{2}{|c|}{ Borrelial Lymphocytoma } & \multicolumn{2}{|c|}{ Acrodermatitis Chronica Atrophicans } \\
\hline & First Intention & Second Intention & First Intention & Second Intention & First Intention & Second Intention \\
\hline ILADS [27] & \multicolumn{2}{|c|}{$\begin{array}{l}\text { Amoxicillin }(1.5-2.0 \mathrm{~g} / \mathrm{d}) \text { or Cefuroxime-axetil } \\
\qquad(500 \mathrm{mg} \times 2 / \mathrm{d}) \\
\text { or Doxycycline }(100 \mathrm{mg} \times 2 / \mathrm{d}) \text { for } 4-6 \text { weeks } \\
\text { or Azithromycin }(250-500 \mathrm{mg} / \mathrm{d}) \text { for } 21 \text { days } \\
\text { minimum } \\
\quad \text { level of evidence }=\text { very low }\end{array}$} & NA & NA & NA & NA \\
\hline SSID and SSN [17] & NA & NA & NA & NA & NA & NA \\
\hline BAPCOC [26] & $\begin{array}{l}\text { Doxycycline }(100 \mathrm{mg} \times \\
2 / \mathrm{d}) \\
\text { for } 10 \text { days } \\
\text { level of evidence }=\mathbf{N A}\end{array}$ & $\begin{array}{c}\text { Amoxicillin }(1.5-2 \mathrm{~g} / \mathrm{d}) \\
\text { or } \\
\text { Cefuroxime-axetil } \\
(500 \mathrm{mg} \times 2 / \mathrm{d}) \text {, or } \\
\text { Clarythromycin }(500 \mathrm{mg} \\
\times 2 / \mathrm{d}) \text { for } 14 \text { days } \\
\text { or Azithromycin }(1 \mathrm{~g} \text { on } \\
\mathrm{D} 1 \text {, then } 500 \mathrm{mg} / \mathrm{d}) \text { for } 4 \\
\text { days } \\
\text { or }(500 \mathrm{mg} / \mathrm{d}) \text { for } 7 \text { days } \\
\text { level of evidence }=\mathrm{NA}\end{array}$ & NA & NA & \multicolumn{2}{|c|}{$\begin{array}{c}\text { Doxycycline }(100 \mathrm{mg} \times 2 / \mathrm{d}) \text { for } 21-28 \text { days } \\
\text { or Ceftriaxone }(2 \mathrm{~g} / \mathrm{d}) \text { for } 14 \text { days } \\
\text { level of evidence }=\text { NA }\end{array}$} \\
\hline AWMF [24] & \multicolumn{2}{|c|}{$\begin{array}{c}\text { Doxycycline }(100 \mathrm{mg} \times 2 / \mathrm{d} \text { or } 200 \mathrm{mg} / \mathrm{d}) \text { for } 10-14 \\
\text { days } \\
\text { or Amoxicillin }(0.5-1 \mathrm{~g} \times 3 / \mathrm{d}) \text { or Cefuroxime axetil } \\
(500 \mathrm{mg} \times 2 / \mathrm{d}) \text { for } 14 \text { days } \\
\text { or Azithromycin }(250 \mathrm{mg} \times 2 / \mathrm{d}) \text { for } 5-10 \text { days } \\
\text { level of evidence }=\text { NA }\end{array}$} & \multicolumn{2}{|c|}{$\begin{array}{l}\text { Doxycycline }(100 \mathrm{mg} \times 2 / \mathrm{d} \text { or } 200 \mathrm{mg} / \mathrm{d}) \text { or } \\
\text { Amoxicillin }(0.5-1 \mathrm{~g} \times 3 / \mathrm{d}) \\
\text { Cefuroxime-axetil }(500 \mathrm{mg} \times 2 / \mathrm{d}) \text {, for } 14-21 \text { days } \\
\text { or Azithromycin }(250 \mathrm{mg} \times 2 / \mathrm{d}) \text { for } 5-10 \text { days } \\
\text { level of evidence }=\text { NA }\end{array}$} & \multicolumn{2}{|c|}{$\begin{array}{c}\text { Doxycycline }(100 \mathrm{mg} \times 2 / \mathrm{d} \text { or } 200 \mathrm{mg} / \mathrm{d}) \text { or } \\
\text { Amoxicillin }(0.5-1 \mathrm{~g} \times 3 / \mathrm{d}) \text { for } 30 \text { days } \\
\text { If associated with neurological symptoms: } \\
\text { Penicillin } \mathrm{G}(4 \times 5 \mathrm{MU} / \mathrm{d}) \text { or Ceftriaxone }(2 \mathrm{~g} / \mathrm{d}) \\
\text { or Cefotaxime }(2 \mathrm{~g} \times 3 / \mathrm{d}) \text { for } 14-21 \text { days } \\
\text { level of evidence }=\text { NA }\end{array}$} \\
\hline
\end{tabular}


Table 3. Cont

\begin{tabular}{|c|c|c|c|c|c|c|}
\hline \multirow{2}{*}{ Guidelines } & \multicolumn{2}{|c|}{ Erythema Migrans } & \multicolumn{2}{|c|}{ Borrelial Lymphocytoma } & \multicolumn{2}{|c|}{ Acrodermatitis Chronica Atrophicans } \\
\hline & First Intention & Second Intention & First Intention & Second Intention & First Intention & Second Intention \\
\hline ESGBOR [18] & $\begin{array}{c}\text { Doxycycline for } 10 \text { days } \\
\text { or Amoxicillin } \\
\text { or Cefuroxime-axetil or } \\
\text { Phenoxymethylpeni- } \\
\text { cillin } \\
\text { for } 14 \text { days } \\
\text { level of evidence = NA }\end{array}$ & $\begin{array}{c}\text { Azithromycin } \\
\text { for 5-10 days, } \\
\text { if CI for } \beta \text {-lactams or } \\
\text { tetracyclines } \\
\text { level of evidence = NA }\end{array}$ & $\begin{array}{c}\text { Doxycycline or } \\
\text { Amoxicillin } \\
\text { or Cefuroxime-axetil or } \\
\text { Phenoxymethylpenicillin } \\
\text { for } 14 \text { days } \\
\text { level of evidence = NA }\end{array}$ & $\begin{array}{c}\text { Azithromycin } \\
\text { for } 5 \text {-10 days, } \\
\text { if CI for } \beta \text {-lactams or } \\
\text { tetracyclines } \\
\text { level of evidence = NA }\end{array}$ & $\begin{array}{c}\text { Doxycycline or } \\
\text { Amoxicillin } \\
\text { or Cefuroxime-axetil or } \\
\text { Phenoxymethylpenicillin } \\
\text { for } 21-28 \text { days } \\
\text { level of evidence = NA }\end{array}$ & $\begin{array}{c}\text { Azithromycin } \\
\text { for 5-10 days, } \\
\text { if CI for } \beta \text {-lactams or } \\
\text { tetracyclins } \\
\text { level of evidence = NA }\end{array}$ \\
\hline HAS [22] & $\begin{array}{c}\text { Doxycycline }(100 \mathrm{mg} \times \\
2 / \mathrm{d} \text { or } 200 \mathrm{mg} / \mathrm{d}) \text { or } \\
\text { Amoxicillin }(1 \mathrm{~g} \times 3 / \mathrm{d}) \text {, } \\
\text { for } 14 \text { days } \\
\text { level of } \\
\text { evidence }=\text { moderate }\end{array}$ & $\begin{array}{c}\text { Azithromycin (1 g on D1, } \\
\text { then } 500 \mathrm{mg} / \mathrm{d}) \text { for } 7 \\
\text { days } \\
\text { level of } \\
\text { evidence = moderate }\end{array}$ & $\begin{array}{c}\text { Doxycycline }(100 \mathrm{mg} \times \\
2 / \mathrm{d} \text { or } 200 \mathrm{mg} / \mathrm{d}) \\
\text { or Amoxicillin }(1-2 \mathrm{~g} \times \\
3 / \mathrm{d}), \text { for } 21 \text { days } \\
\text { level of evidence }=\text { low }\end{array}$ & $\begin{array}{c}\text { Azithromycin (1 g on D1, } \\
\text { then } 500 \mathrm{mg} / \mathrm{d} \text { ) for } 10 \\
\text { days } \\
\text { level of evidence = low }\end{array}$ & $\begin{array}{c}\text { Doxycycline }(200 \mathrm{mg} / \mathrm{d}) \\
\text { for } 28 \text { days } \\
\text { level of evidence = low }\end{array}$ & $\begin{array}{c}\text { Ceftriaxone }(2 \mathrm{~g} / \mathrm{d}) \\
\text { for } 28 \text { days } \\
\text { level of evidence }=\text { low }\end{array}$ \\
\hline NICE [23] & $\begin{array}{l}\text { Doxycycline }(100 \mathrm{mg} \times \\
2 / \mathrm{d} \text { or } 200 \mathrm{mg} / \mathrm{d}) \text { for } 21 \\
\quad \text { days } \\
\text { level of evidence }=\text { low }\end{array}$ & $\begin{array}{c}\text { Amoxicillin }(1 \mathrm{~g} \times 3 / \mathrm{d}) \\
\text { for } 21 \text { days } \\
\text { or Azithromycin } \\
(500 \mathrm{mg} / \mathrm{d}) \text { for } 17 \text { days } \\
\text { level of evidence }=\text { low }\end{array}$ & NA & NA & $\begin{array}{c}\text { Doxycycline }(100 \mathrm{mg} \times \\
2 / \mathrm{d} \text { or } 200 \mathrm{mg} / \mathrm{d}) \text { for } \\
28 \text { days } \\
\text { level of evidence }=\text { low }\end{array}$ & $\begin{array}{c}\text { Amoxicillin }(1 \mathrm{~g} \times 3 / \mathrm{d}) \\
\text { or Ceftriaxone }(2 \mathrm{~g} / \mathrm{d}) \\
\text { for } 28 \text { days } \\
\text { level of evidence = low }\end{array}$ \\
\hline AWMF [25] & NA & NA & NA & NA & NA & NA \\
\hline $\begin{array}{l}\text { French scientific } \\
\text { societies [7] }\end{array}$ & $\begin{array}{c}\text { Doxycycline }(100 \mathrm{mg} \times \\
2 / \mathrm{d}) \\
\text { for } 14 \text { days } \\
\text { level of } \\
\text { evidence }=\text { grade } \mathbf{B}\end{array}$ & $\begin{array}{c}\text { Amoxicillin }(1 \mathrm{~g} \times 3 / \mathrm{d}) \\
\text { for } 14 \text { days } \\
\text { level of } \\
\text { evidence }=\text { grade } \mathbf{B}\end{array}$ & $\begin{array}{c}\text { Doxycycline }(100 \mathrm{mg} \times \\
2 / \mathrm{d}) \\
\text { for } 21 \text { days } \\
\text { level of evidence = } \\
\text { grade } \mathbf{B}\end{array}$ & $\begin{array}{c}\text { Amoxicillin }(1 \mathrm{~g} \times 3 / \mathrm{d}) \\
\text { for } 21 \text { days } \\
\text { level of } \\
\text { evidence }=\text { grade } \mathbf{B}\end{array}$ & $\begin{array}{c}\text { Doxycycline }(200 \mathrm{mg} / \mathrm{d}) \\
\text { for } 28 \text { days } \\
\text { level of } \\
\text { evidence }=\text { grade } \mathbf{B}\end{array}$ & $\begin{array}{l}\text { Ceftriaxone }(2 \mathrm{~g} / \mathrm{d}) \\
\text { for } 28 \text { days } \\
\text { level of } \\
\text { evidence }=\text { grade } \mathbf{B}\end{array}$ \\
\hline Canada [21] & $\begin{array}{c}\text { Doxycycline }(100 \mathrm{mg} \times \\
2 / \mathrm{d}) \\
\text { for } 14 \text { days } \\
\text { level of evidence }=\mathbf{N A}\end{array}$ & $\begin{array}{c}\text { Amoxicillin }(0.5 \mathrm{~g} \times 3 / \mathrm{d}) \\
\text { or Cefuroxime-axetil } \\
(500 \mathrm{mg} \times 2 / \mathrm{d}) \\
\text { for penicillin-allergic } \\
\text { patient, } \\
\text { for } 14 \text { days } \\
\text { level of evidence }=\mathrm{NA}\end{array}$ & NA & NA & NA & NA \\
\hline
\end{tabular}


Table 3. Cont.

\begin{tabular}{|c|c|c|c|c|}
\hline \multirow{2}{*}{ Guidelines } & \multicolumn{2}{|c|}{ Erythema Migrans } & Borrelial Lymphocytoma & Acrodermatitis Chronica Atrophicans \\
\hline & First Intention & Second Intention & Second Intention & Second Intention \\
\hline IDSA [19] & $\begin{array}{c}\text { Doxycycline }(100 \mathrm{mg} \times \\
2 / \mathrm{d} \text { or } 200 \mathrm{mg} / \mathrm{d}) \text { for } \\
10 \text { days } \\
\text { or Amoxicillin } \\
(0.5 \mathrm{~g} \times 3 / \mathrm{d}) \\
\text { or Cefuroxime-axetil } \\
(500 \mathrm{mg} \times 2 / \mathrm{d}) \\
\text { for } 14 \text { days } \\
\text { level of } \\
\text { evidence }=\text { moderate }\end{array}$ & $\begin{array}{c}\text { Azithromycin } \\
(500 \mathrm{mg} / \mathrm{d}) \\
\text { for } 5-10 \text { days } \\
\text { level of } \\
\text { evidence }=\text { moderate }\end{array}$ & $\begin{array}{l}\text { Doxycycline }(100 \mathrm{mg} \times 2 / \mathrm{d} \text { or } 200 \mathrm{mg} / \mathrm{d}) \text { for } 21 \text { days } \\
\text { or Amoxicillin }(0.5-1 \mathrm{~g} \times 3 / \mathrm{d}) \text { for } 14 \text { days } \\
\text { or Cefuroxime-axetil }(500 \mathrm{mg} \times 2 / \mathrm{d}) \text { for } 14-21 \text { days } \\
\text { level of evidence }=\text { low }\end{array}$ & $\begin{array}{l}\text { Doxycycline }(100 \mathrm{mg} \times 2 / \mathrm{d} \text { or } 200 \mathrm{mg} / \mathrm{d}) \text { or } \\
\text { Amoxicillin }(0.5-1 \mathrm{~g} \times 3 / \mathrm{d}) \\
\text { or Cefuroxime-axetil }(500 \mathrm{mg} \times 2 / \mathrm{d}) \text { for } 21-28 \text { days } \\
\text { level of evidence }=\text { low }\end{array}$ \\
\hline
\end{tabular}

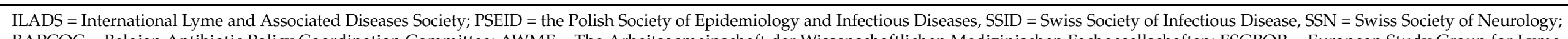

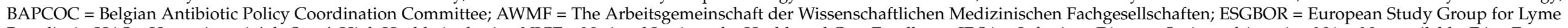

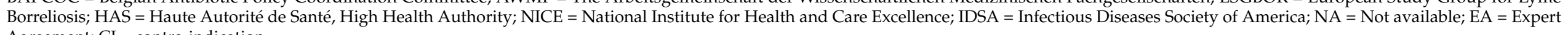
Agreement; $\mathrm{CI}=$ contra-indication . 
The Belgian guidelines were based on 7 articles [26], the German ones on 1 article and on American and European guidelines [24], the European ones on 7 articles [18], and the Canadian ones cited a previous Canadian guideline [21]. Only three guidelines were elaborated according to the Grading of Recommendations Assessment, Development, and Evaluation (GRADE) approach $[7,19,27]$ : the French scientific societies' guidelines were based on 4 articles that evaluated the recommendation as grade B [7], the IDSA guidelines were based on 41 references that evaluated the recommendations as possessing strong to moderate quality of evidence [19], and the ILADS guidelines were based on 9 references that evaluated the available studies as having low evidence for their recommendation [27]. Despite the analysis of common articles [28-36] and the same methodology (GRADE) the conclusions of these three guidelines were widely different $[7,19,27]$. The reason lies in the interpretation of the literature.

The two main cited articles were both randomized double-blind trials [32,37]. In the first, 246 adult patients with EM received amoxicillin $500 \mathrm{mg} \times 3 / \mathrm{d}$ for 20 days or azithromycin $500 \mathrm{mg} / \mathrm{d}$ and a placebo for 7 days. Patients treated with amoxicillin were significantly more likely than those treated with azithromycin to achieve complete resolution of disease at day $20(p=0.024)$ and had less relapse $(p=0.005)$. The authors concluded that a 20-day course of amoxicillin was effective for EM [32]. The second trial included 180 patients with EM and compared 10 days of oral doxycycline with or without a single intravenous dose of ceftriaxone or 20 days of oral doxycycline. In the on-study analysis, the complete response rate at 30 months was $83.9 \%$ in the 20 -day doxycycline group, $90.3 \%$ in the 10 -day doxycycline group and $86.5 \%$ in the doxycycline-ceftriaxone group $(p>0.2)$. There were no significant differences in the results of neurocognitive testing among the three treatment groups and a control group without LB. Diarrhea occurred significantly more often in the doxycycline-ceftriaxone group $(35 \%)(p<0.001)$. The authors concluded that extending treatment with doxycycline from 10 to 20 days or adding one dose of ceftriaxone to a 10-day course of doxycycline did not enhance therapeutic efficacy in patients with EM [37].

While amoxicillin (1.5 to $3 \mathrm{~g} / \mathrm{d})$ and doxycycline $(200 \mathrm{mg} / \mathrm{d})$ were recommended for EM treatment in 10/10 guidelines, cefuroxime-axetil $(500 \mathrm{mg} \times 2)$ was recommended for 14 to 28 days in 6/10 [19,20,24,26,38] and for 4 to 6 weeks in 1/10 [27]. Azithromycin was also recommended with various doses and various lengths (5-10 days) in 5/10 guidelines $[18,19,22,24,26]$. Clarithromycin and phenoxymethylpenicillin were only recommended in one guideline each $[18,26]$.

Evidence shows no clear difference between doxycycline, amoxicillin and azithromycin in patients with EM except for one trial [32]. Therefore, azithromycin is sometimes considered as a second-line agent, with some efficacy concerns. Three guidelines $[18,19,26]$ underscored this discordant result for azithromycin without a clear explanation apart from methodological differences; other guidelines considered azithromycin to be adequately effective without restriction or discussion [23,24,27].

The recommended length of treatment varies from 10 to 14 days in most guidelines [7,18,19,22,26], but it was increased to 21 [23], or 28 days [20] or 4-6 weeks [27] in 3 outsiders. To assess the need for prolonged treatment, the ILADS working group performed a Medline search for prospective randomized clinical trials investigating the effectiveness of 5-20 days of oral azithromycin, cefuroxime, doxycycline, phenoxymethylpenicillin, or amoxicillin for the treatment of EM [27]. Of the 76 papers identified, 9 were evaluated [28-30,32,33,35,36,39]. The authors concluded that the evidence quality was low and insufficient to recommend a short treatment (<21 days) [27]. Nevertheless, no study was cited to assess the superiority or the non-inferiority of prolonged treatment because no randomized controlled trial explored treatment longer than 21 days [27].

Borrelial Lymphocytoma (BL)

Regarding BL, only 6/12 guidelines edited recommendations [7,18-20,22,24]. All these guidelines recommended the use of amoxicillin $(1.5$ to $3 \mathrm{~g} / \mathrm{d})$ or doxycycline $(200 \mathrm{mg} / \mathrm{d})$ in the 
first intention. The use of azithromycin with various doses was less consensual $[18,22,24]$, and cefuroxime axetil $(500 \mathrm{mg} \times 2 / \mathrm{d})$ was recommended in only $4 / 6$ [7,20,22,24].

Treatment duration for BL with amoxicillin or doxycycline varied from 14 to 28 days, mostly 14 to 21 days in $4 / 6$ guidelines $[7,20,22,24]$. These discrepancies are probably due to the absence of available randomized controlled trials. German Dermatology Society guidelines and the two French guidelines provided a duration of 21 days because BL indicates a disseminated LB $[7,22,24]$ whereas no explanation on duration choice is given for other guidelines [10-12]. The recommendations levels were weak, when specified (grade B for French scientific societies guidelines and weak recommendation of low quality for IDSA), based on extremely few references. Only a case report [39] and 4 cohorts assessed these choices.

Acrodermatitis Chronica Atrophicans (ACA)

All but four guidelines provided recommendations for the treatment of ACA $[7,18-20,22-24,26]$. Because no randomized controlled trial for treatment duration for ACA was published, guidelines were based on cohort studies [38,40-44], with low quality of evidence, mainly because of the low number of patients.

The recommended duration was homogenous, longer than 21 days $[7,18,19,22-24,26]$, except for Polish guidelines [20] without any supplementary explanation. In the same way, recommendations for antibiotic choice were homogeneous. Doxycycline $(200 \mathrm{mg} / \mathrm{d})$ was recommended to treat ACA in all guidelines $[7,18-20,22-24,26]$ and ceftriaxone $(2 \mathrm{~g} / \mathrm{d})$ in $6 / 8$ guidelines $[7,20,22,23,26]$, specifically if associated with neurological symptoms in a German Dermatology Society guideline [24]. Amoxicillin (1.5 to $3 \mathrm{~g} / \mathrm{d}$ ) was recommended in 5/8 [18-20,23,24] and cefuroxime axetil $(500 \mathrm{mg} \times 2)$ in $3 / 8$ guidelines [18-20].

\section{Children and Pregnant Women}

Guidelines in children were mentioned in $9 / 10$ guidelines $[7,18,19,21-24,26,27]$. For EM treatment in children under eight years old, doxycycline is avoided based on experience with older tetracyclines (staining of permanent teeth). This adverse effect has not been reported with doxycycline, and some studies reported its good tolerability in children for a duration of up to 14 days [25]. The recommended treatments followed the adult schemes in all guidelines $[7,10,11,13-16,18,19]$ with dose adaptation. Amoxicillin was prescribed at $50 \mathrm{mg} / \mathrm{kg} / \mathrm{d}$ in three divided doses $[7,21,22,24,26,27]$ except in NICE guidelines in which amoxicillin was proposed at $30 \mathrm{mg} / \mathrm{kg} / \mathrm{d}$ until 33kg [23]. When recommended, cefuroximeaxetil dose was $30 \mathrm{mg} / \mathrm{kg} / \mathrm{d}$ in two divided doses [21,24,26,27]. Azithromycin dose varied according to recommendations: $10 \mathrm{mg} / \mathrm{kg}$ on day 1 , then $5-10 \mathrm{mg} / \mathrm{kg} / \mathrm{d}$ [27], $20 \mathrm{mg} / \mathrm{kg}$ on day 1 and $10 \mathrm{mg} / \mathrm{kg} / \mathrm{d}$ for 4 days [26], $20 \mathrm{mg} / \mathrm{kg} / \mathrm{d}$ for 4 days [7], and $10 \mathrm{mg} / \mathrm{kg} / \mathrm{d}$ until $50 \mathrm{~kg}$ for 17 days [23]. In the French scientific societies guidelines, azithromycin was not recommended for adult patients but was possible for children under eight years old only in cases of allergy to beta-lactams (dose $20 \mathrm{mg} / \mathrm{kg} / \mathrm{d}$, $\max 500 \mathrm{mg} / \mathrm{f}$, for 5 days) [7]. When children are over eight years old, the recommended dose for doxycycline is $4 \mathrm{mg} / \mathrm{kg} / \mathrm{d}$ in two divided doses, with a maximum of $200 \mathrm{mg} / \mathrm{d}$. Of note, the IDSA guidelines suggested further study to establish the safety profile of doxycycline in children but stated that data are reassuring on the safety of short courses of doxycycline [19].

Most guidelines raised awareness about the molecules when contraindicated in pregnancy $[18,19,21,23,26]$. Polish guidelines recommended the use of $\beta$-lactams for the treatment of BL in pregnant women [20]. Other recommendations were more specific: amoxicillin was the first line in all the recommendations, giving specific treatment for pregnant women $[7,19,22,24]$. Azithromycin was the second-line agent in the French High Health Authority guidelines [22], while German guidelines recommended as a second line Penicillin G (IV) or ceftriaxone (IV) [24]. Cefuroxime, ceftriaxone, cefotaxime or azithromycin were placed as the third line of treatment in these German guidelines [24]. 


\subsubsection{Treatment of Lyme Neuroborreliosis (LNB) (cf. Table 4)}

Lyme neuroborreliosis (LNB) is the most common manifestation of disseminated LB in Europe. The two main molecules recommended by all guidelines were oral doxycycline and intravenous ceftriaxone. European studies have shown similar efficacy of doxycycline for the treatment of early LNB compared to parenteral ceftriaxone. Because the number of patients with severe LNB (encephalitis, encephalomyelitis) was limited in these studies, some guidelines recommended ceftriaxone as the first choice for the treatment of LNB with central nervous system (CNS) involvement pending more robust data $[18,20,22,26]$. However, complications related to intravenous treatment, such as thrombophlebitis and secondary infections, would be avoided by using oral antibiotics, also associated with lower costs, and a higher degree of patient satisfaction [45]. Therefore, most guidelines recommended the use of oral doxycycline rather than intravenous treatment $[7,19,20,23,25,26]$. NICE and IDSA guidelines recommended ceftriaxone as first-line therapy only for LNB with central nervous system impairment $[19,23]$. For the treatment of late LNB (evolution $>6$ months), all guidelines recommended ceftriaxone as first-line therapy except the French scientific societies guidelines, which left the choice between doxycycline and ceftriaxone for the first line considering the explanations above [7]. Only NICE and IDSA guidelines did not specify therapy for late LNB but differentiated between CNS and peripheral nervous system (PNS) involvement $[19,23]$. Of note, only the IDSA and the German guidelines proposed the use of cefotaxime and Penicillin G for the treatment of LNB [19,25]. However, these two molecules are more difficult to manage compared to ceftriaxone because of shorter half-lives (Table 4).

Dosage of doxycycline was $100 \mathrm{mg} \times 2$ /day for all guidelines except for the German and IDSA guidelines, which recommended an increased dosage of $300 \mathrm{mg}$ in 1 or 3 divided doses or $200 \mathrm{mg}$ in 1 dose $[19,25]$. The French scientific societies suggested $200 \mathrm{mg} \times 2 / \mathrm{d}$ for CNS LNB [7]. Similarly, NICE guidelines recommended intravenous ceftriaxone $4 \mathrm{~g} /$ day as the initial treatment for adults and teenagers (age 12 and over) with LNB affecting the CNS whereas all other guidelines recommended $2 \mathrm{~g} /$ day [15]. These differences may be related to pharmacokinetics concerns and higher doses of ceftriaxone being routinely recommended for bacterial meningitis (i.e., $70-100 \mathrm{mg} / \mathrm{kg} /$ day). Doxycycline, with a daily dose of $200 \mathrm{mg}$, does not reach the minimal bactericidal and inhibitory concentrations for all strains of B. burgdorferi in the cerebrospinal fluid [14,46-48]. However, most prospective studies used a dosage of $200 \mathrm{mg} /$ day [ $47,49,50]$. One study used doxycycline $400 \mathrm{mg} /$ day and another $200 \mathrm{mg}$ for 2 days then $100 \mathrm{mg} /$ day for the remaining 8 days [51,52]. No studies compared different dosages.

Treatment duration varied from 14 to 28 days in different guidelines depending on the type of neurologic impairment. These differences depended on the interpretation of the literature. Most studies analysed in the guidelines included patients with early LNB [52-55]. The duration of treatment in randomized controlled trials was mainly 10-14 days [52-55]. Results of two randomized controlled studies showed no benefit from an antibiotic therapy longer than 28 days $[9,56]$. However, Cadavid et al. reported in a systematic review a low to an extremely low quality of clinical evidence of studies about LNB because of the limited number and heterogeneous trials [57]. Kortela et al. reported, in a randomized, open-label trial, 210 adults with suspected LNB treated with oral doxycycline for 28 days or intravenous ceftriaxone for 21 days [58]. Late LNB represented 10\% of cases. Patients improved equally well with both treatment regimens. Of note, there was no clear benefit from longer treatments, with a persistence of residual symptoms [58]. However, this study was too recent to be included in guidelines.

\section{Children and Pregnant Women}

There was limited evidence on the use of antibiotics to treat LNB in children, and available studies are of poor quality [59]. All guidelines recommended the same treatment for children aged 9 to 12 than for adults and teenagers but with doses adjusted by weight: doxycycline $2.5-5 \mathrm{mg} / \mathrm{kg}$, ceftriaxone $50-80 \mathrm{mg} / \mathrm{kg}$. The use of doxycycline in children 
under 9 years old is currently limited by licensing and clinical experience. Some guidelines discussed the place of doxycycline in children's LNB, especially when beta-lactams are contraindicated or when the intravenous line is difficult to manage $[7,19]$. However, doxycycline may be prescribed in children younger than eight years old only after having informed the parents that such treatment does not have a marketing authorization for use in this population.

Five out of eight recommendations contraindicated doxycycline in pregnant women $[7,20,22,23,25]$ because of the staining of permanent teeth in their babies. Based on experience with older tetracycline, not with doxycycline, IDSA guidelines specified that the safety of doxycycline in pregnancy and breastfeeding required more study, and thus, the decision to use doxycycline in these patients should be individualized to the likely risks and benefits of alternative antibiotics [27]. In the same way, Belgium's recommendations contraindicated tetracycline in the second trimester of pregnancy but not doxycycline [26]. French recommendations indicated that doxycycline administered after the first trimester of pregnancy was associated with a risk of coloration of deciduous teeth, without any impact on permanent teeth $[7,22]$. However, they recommended amoxicillin or ceftriaxone as first-line treatment depending on the disease stage in pregnant women $[7,22]$.

\subsubsection{Treatment of Lyme Arthritis (cf. Table 4)}

Seven guidelines dealt with the treatment of LA [7,18-20,22,23,26]. There was no clear distinction made on the treatment of forms that had been evolving for less (early LA) or more (late LA) than six months in any guidelines [7,18-20,22,23,26].

Two leading articles were cited in 5/7 guidelines. Steere et al. (1985) demonstrated in a double-blind placebo-controlled trial in 40 patients with established LA that 2.4 million UI of intramuscular benzathine penicillin weekly for three weeks $(n=20)$ was superior to placebo $(n=20)$ with $35 \%$ favorable outcome soon afterwards $(p<0.02)$ [60]. This study was the first to show the efficacy of an antibiotherapy for LA, but the regimens that were tested were not uniformly effective, suggesting that further studies would be needed to determine the optimal course of therapy [60]. Steere et al. (1994) performed a randomized controlled trial comparing doxycycline or amoxicillin-probenecid and a placebo for 30 days in patients presenting LA, defined as clinical arthritis and positive serology for Borrelia [61]. Meanwhile, 18/20 patients and 16/20 patients respectively treated by doxycycline and amoxicillin-probenecid had their arthritis resolved within 1 to 3 months (complete answer to antibiotics at $48 \%$ vs. $0 \%$ for placebo, $p=0.02$ ) [61]. Nonetheless, 5 patients developed LNB later, 4 of whom had received the amoxicillin-probenecid regimen [61]. Moreover, another group of 16 additional patients who had persistent arthritis for at least 3 months after treatment with oral antibiotics or parenteral penicillin was given intravenous ceftriaxone for 2 weeks, and none had resolution of arthritis within 3 months [61]. Authors concluded that LA could be treated by oral antibiotics, but patients may still develop LNB, and patients with certain genetic and immune markers may have persistent arthritis despite treatment with oral or intravenous antibiotics [61].

Two randomized controlled trials conducted by Dattwyler et al., cited in $4 / 7$ guidelines, investigated (i) the efficacy of ceftriaxone vs. penicillin, and (ii) two durations of antibiotic therapy (14 days vs. 28 days) [62,63]. An extended duration of 28 days showed a better response without achieving statistical significance $(p=0.07)$ and presented more side effects $(p<0.02)$ [62]. Intravenous ceftriaxone seemed more effective than intravenous penicillin but with a small sample size $(n=23)$ [64]. In 31 patients, ceftriaxone $4 \mathrm{~g} / \mathrm{d}$ was not superior to ceftriaxone $2 \mathrm{~g} / \mathrm{d}$ [64].

Several cohort studies, cited in $2 / 7$ guidelines, described the clinical evolution of patients treated for late LA, mainly by doxycycline, ceftriaxone, cefuroxime-axetil and amoxicillin [64-67]. A complete response was noted in $45 \%$ to $75 \%$ of cases after the first line of antibiotic therapy for $3-4$ weeks and in $20 \%$ to $25 \%$ after a second line. Oral therapy presented fewer side effects. 
All these studies enable us to conclude that several antibiotics are effective among doxycycline, ceftriaxone, and amoxicillin for LA, although data about their optimal doses and duration are limited. Ceftriaxone and doxycycline seemed both as effective as and more effective than amoxicillin or intravenous penicillin. Intravenous ceftriaxone presented more adverse events than oral therapy. The data suggested the superiority of a 28-day treatment compared to a 14-day treatment but with a low level of evidence. About a quarter of the patients presented refractory arthritis after the second line of antibiotics despite the absence of Borrelia in the articular liquid, suggesting an inflammatory process responding to anti-inflammatory therapies. Of note, no studies directly assessed the efficacy of cefuroxime-axetil versus other oral antibiotics or placebo in the treatment of LA. Evidence is inferred from studies of its efficacy in the treatment of early manifestations [19].

Doxycycline was recommended at the first line in all the guidelines $[7,18-20,22,23,26]$. Four of seven guidelines proposed other molecules at the first line as well (ceftriaxone, amoxicillin or cefuroxime-axetil) [18-20,26]. The IDSA guidelines were the only ones to suggest cefuroxime-axetil at the first line, and the ESGBOR guidelines were the only other ones to recommend it in the second line [18,19]. All the guidelines except the Polish ones recommended ceftriaxone at the second line $[7,18,19,22,23,26]$. The IDSA, ESGBOR and Belgium guidelines recommended amoxicillin at the first line on the same level as doxycycline $[18,19,26]$.

The recommended duration was 28 days in all the guidelines for all the molecules except for ceftriaxone for which the IDSA, ESGBOR and Belgium guidelines suggested 14 to 28 days $[18,19,26]$. Seven guidelines recommended a second line of antibiotic therapy in case of failure after one month and suggested trying another molecule than the first $[7,18-20,22,23,26]$.

All guidelines were homogeneous about the doses of all the antibiotics (doxycycline $200 \mathrm{mg} / \mathrm{d}$, ceftriaxone $2 \mathrm{~g} / \mathrm{d}$, cefuroxime-axetil $500 \mathrm{mg} \times 2 / \mathrm{d}$ ) except for amoxicillin for which the Belgium and IDSA guidelines recommended $500 \mathrm{mg} \times 3 / \mathrm{d}$ instead of $1 \mathrm{~g} \times 3 / \mathrm{d}[19,26]$. The rationale for recommending $1 \mathrm{~g} \times 3 / \mathrm{d}$ is the included study using probenecid to increase the concentration of amoxicillin [62].

To conclude, these seven guidelines recommend doxycycline $200 \mathrm{mg} / \mathrm{d}$ at the first line for 28 days and ceftriaxone $2 \mathrm{~g} / \mathrm{d}$ at the second line from 14 to 28 days, but with moderate to low evidence. In case of failure of the first line, another month of antibiotic therapy was recommended, changing the molecule. The differences between the guidelines can be explained by the absence of randomized controlled trials comparing the efficacy of the molecules between them and their optimal durations.

\section{Children and Pregnant Women}

Children were mentioned in $5 / 7$ guidelines with a low level of evidence $[7,18,22,23,26]$. For children under eight years old, amoxicillin was the first-line therapy for 28 days: $30 \mathrm{mg} / \mathrm{kg} \times 3 / \mathrm{d}$ in NICE guidelines [23], $80 \mathrm{mg} / \mathrm{kg} / \mathrm{d}$ [7] or $100 \mathrm{mg} / \mathrm{kg} / \mathrm{d}$ in 3 divided doses in the French guidelines [22] and $50 \mathrm{mg} / \mathrm{kg} / \mathrm{d}$ in 3 divided doses in the Belgium guidelines [26]. The second line was ceftriaxone $80 \mathrm{mg} / \mathrm{kg} / \mathrm{d}$ for 28 days $[7,22,23]$. The Belgium guidelines suggested ceftriaxone $100 \mathrm{mg} / \mathrm{kg} / \mathrm{d}(\max 2 \mathrm{~g} / \mathrm{d}$ ) at the first line as well, at the same level as amoxicillin [26]. For children over nine years old, doxycycline was recommended as first-line therapy: $4 \mathrm{mg} / \mathrm{kg} / \mathrm{j}$ (max $200 \mathrm{mg} / \mathrm{d}][7,22,26]$ or $5 \mathrm{mg} / \mathrm{kg} / \mathrm{j}$ on day 1 then $2.5 \mathrm{mg} / \mathrm{kg} / \mathrm{d}$ for 28 days [23]. In the French guidelines, ceftriaxone $2 \mathrm{~g} / \mathrm{d}$ for 28 days was the first-line therapy for pregnant women [7,22]. The ESGBOR guidelines only mentioned that doxycycline should be avoided in children under eight years old and in pregnant or breastfeeding women [18]. The IDSA guidelines made no difference for children, adults and pregnant women because data are reassuring on the safety of short courses of doxycycline in these populations [19]. 
Table 4. Comparative table of the treatment recommended in the European and American guidelines for Lyme neuroborreliosis and Lyme arthritis.

\begin{tabular}{|c|c|c|c|c|c|}
\hline \multirow[t]{2}{*}{ Guidelines } & Early Lyme Neuroborreliosis & \multicolumn{2}{|c|}{ Late Lyme Neuroborreliosis } & \multicolumn{2}{|c|}{$\begin{array}{l}\text { Early (<6 Months) and Late (>6 Months) } \\
\text { Lyme Arthritis }\end{array}$} \\
\hline & Second Intention & First Intention & Second Intention & First Intention & Second Intention \\
\hline ILADS [27] & NA & NA & NA & NA & NA \\
\hline PSEID [20] & $\begin{array}{c}\text { Cranial nerves deficit: } \\
\text { Doxycycline } 100 \mathrm{mg} \times 2 / \mathrm{d} \text { for } 14-28 \text { days } \\
\text { Meningitis, radiculitis, vasculitis: } \\
\text { Doxycycline }(100 \mathrm{mg} \times 2 / \mathrm{d}) \text { or Ceftriaxone }(2 \mathrm{~g} / \mathrm{d}) \\
\text { for } 14-28 \text { days } \\
\text { level of evidence }=\text { NA }\end{array}$ & \multicolumn{2}{|c|}{$\begin{array}{c}\text { Encephalomyelitis, radiculoneuritis, meningitis, } \\
\text { occlusive } \\
\text { vasculitis stroke: } \\
\text { Ceftriaxone }(2 \mathrm{~g} / \mathrm{d}) \text { for } 21-28 \text { days. } \\
\text { level of evidence = NA }\end{array}$} & $\begin{array}{l}\text { Doxycycline }(100 \mathrm{mg} \times \\
2 / \mathrm{d}) \\
\text { Or Ceftriaxone }(2 \mathrm{~g} / \mathrm{d}) \\
\text { for } 28-30 \text { days } \\
\text { level of evidence = NA }\end{array}$ & $\begin{array}{l}\text { If failure: continue the } \\
\text { antibiotics one more } \\
\text { month } \\
\text { level of evidence = NA }\end{array}$ \\
\hline SSID and SSN [17] & NA & NA & NA & NA & NA \\
\hline ВАРCOC [26] & $\begin{array}{c}\text { Doxycycline }(100 \mathrm{mg} \times 2 / \mathrm{d}) \text { or Ceftriaxone }(2 \mathrm{~g} / \mathrm{d}) \\
\text { for } 14 \text { days } \\
\text { level of evidence }=\text { NA }\end{array}$ & $\begin{array}{r}\text { Ceftriaxone }(2 \\
\text { level of ev }\end{array}$ & $\begin{array}{l}\text { (d), for } 28 \text { days } \\
\text { lence = NA }\end{array}$ & $\begin{array}{l}\text { Doxycycline }(100 \mathrm{mg} \times \\
2 / \mathrm{d}) \text { or Amoxicillin } \\
(500 \mathrm{mg} \times 3 / \mathrm{d}) \text {, for } \\
28 \text { days } \\
\text { level of evidence = NA }\end{array}$ & $\begin{array}{l}\text { If failure: Ceftriaxone } \\
(2 \mathrm{~g} / \mathrm{d}) \\
\text { for } 14-28 \text { days or } \\
\text { another oral line for } \\
28 \text { days } \\
\text { level of evidence = NA }\end{array}$ \\
\hline AWMF [24] & NA & NA & NA & NA & NA \\
\hline ESGBOR [18] & $\begin{array}{c}\text { For ambulatory patient: Doxycycline }(100 \mathrm{mg} \times 2 / \mathrm{d}) \\
\text { for } 14 \text { days } \\
\text { For hospitalized patients: Ceftriaxone }(2 \mathrm{~g} / \mathrm{d}) \text { for } \\
14 \text { days } \\
\text { level of evidence }=\text { NA }\end{array}$ & $\begin{array}{r}\text { Encephalomyelitis: } \\
14-2 \\
\text { level of ev }\end{array}$ & $\begin{array}{l}\text { eftriaxone }(2 \mathrm{~g} / \mathrm{d}) \text { for } \\
\text { days } \\
\text { lence = NA }\end{array}$ & $\begin{array}{c}\text { Doxycycline or } \\
\text { Amoxicillin for } 28 \text { days } \\
\text { level of evidence }=\text { NA }\end{array}$ & $\begin{array}{l}\text { If failure: Ceftriaxone for } \\
14-28 \text { days } \\
\text { Or Cefuroxime-axetil for } \\
28 \text { days } \\
\text { level of evidence = NA }\end{array}$ \\
\hline HAS [22] & $\begin{array}{c}\text { Ceftriaxone }(2 \mathrm{~g} / \mathrm{d}) \text { or Doxycycline }(100 \mathrm{mg} \times 2 / \mathrm{d}) \\
\text { for } 21 \text { days } \\
\text { Children with isolated nerve palsy: } \\
\text { Amoxicillin }(100 \mathrm{mg} / \mathrm{kg} / \mathrm{d} \times 3 / \mathrm{d}) \text { for } 21 \text { days } \\
\text { level of evidence }=\mathbf{N A}\end{array}$ & $\begin{array}{c}\text { Ceftriaxone }(2 \mathrm{~g} / \mathrm{d}) \\
(100 \mathrm{mg} / \mathrm{kg} / \mathrm{d}) \text { for } \\
28 \text { days } \\
\text { level of evidence = NA }\end{array}$ & $\begin{array}{l}\text { Doxycycline }(100 \mathrm{mg} \times \\
2 / \mathrm{d} \text { or } 4 \mathrm{mg} / \mathrm{kg} / \mathrm{d}) \text { or } \\
\text { Penicillin } \mathrm{G}(24 \mathrm{MU} / \mathrm{d}) \\
\quad \text { for } 28 \text { days } \\
\text { level of evidence }=\text { NA }\end{array}$ & $\begin{array}{l}\text { Doxycycline }(200 \mathrm{mg} / \mathrm{d}) \\
\text { for } 28 \text { days } \\
\text { level of evidence }=\text { low }\end{array}$ & $\begin{array}{c}\text { If failure: Ceftriaxone } \\
(2 \mathrm{~g} / \mathrm{d}) \\
\text { for } 28 \text { days } \\
\text { level of evidence }=\text { low }\end{array}$ \\
\hline
\end{tabular}


Table 4. Cont.

\begin{tabular}{|c|c|c|c|c|c|c|}
\hline \multirow[t]{2}{*}{ Guidelines } & \multicolumn{2}{|c|}{ Early Lyme Neuroborreliosis } & \multicolumn{2}{|c|}{ Late Lyme Neuroborreliosis } & \multicolumn{2}{|c|}{$\begin{array}{c}\text { Early (<6 Months) and Late ( }>6 \text { Months) } \\
\text { Lyme Arthritis }\end{array}$} \\
\hline & First Intention & Second Intention & First Intention & Second Intention & First Intention & Second Intention \\
\hline NICE [23] & $\begin{array}{c}\text { PNS: Doxycycline }(100 \\
\mathrm{mg} \times 2 / \mathrm{d} \text { or } 200 \mathrm{mg} / \mathrm{d}) \\
\text { for } 21 \text { days } \\
\text { CNS: Ceftriaxone }(2 \mathrm{~g} \times \\
2 / \mathrm{d} \text { or } 4 \mathrm{~g} / \mathrm{d}) \\
\text { for } 21 \text { days } \\
\text { level of evidence }= \\
\text { moderate/very low }\end{array}$ & $\begin{array}{c}\text { PNS: Amoxicillin }(1 \mathrm{~g} \times \\
\text { 3/d) for } 21 \text { days } \\
\mathrm{CNS}: \text { Doxycycline }(200 \\
\mathrm{mg} \times 2 / \mathrm{d} \text { or } 400 \mathrm{mg} / \mathrm{d}) \\
\text { for } 21 \text { days } \\
\text { level of evidence }= \\
\text { moderate/ very low }\end{array}$ & NA & NA & $\begin{array}{l}\text { Doxycycline }(100 \mathrm{mg} \times \\
2 / \mathrm{d} \text { or } 200 \mathrm{mg} / \mathrm{d}) \text { for } \\
28 \text { days } \\
\text { level of evidence = low } \\
\text { /very low }\end{array}$ & $\begin{array}{c}\text { 1st Alternative or failure: } \\
\text { Amoxicillin } \\
(1 \mathrm{~g} \times 3 / \mathrm{d}) \text { for } 28 \text { days } \\
\text { 2nd alternative or failure: } \\
\text { Ceftriaxone }(2 \mathrm{~g} / \mathrm{d}) \text { for } \\
28 \text { days } \\
\text { level of evidence }= \\
\text { low/very low }\end{array}$ \\
\hline AWMF [25] & \multicolumn{2}{|c|}{$\begin{array}{c}\text { Doxycycline }(100 \mathrm{mg} \times 2 / \mathrm{d} \text { or } 100 \mathrm{mg} \times 3 / \mathrm{d} \text { or } \\
200-300 \mathrm{mg} / \mathrm{d}) \\
\text { or Ceftriaxone }(2 \mathrm{~g} / \mathrm{d}) \text { or Penicillin } \mathrm{G}(5 \mathrm{MU} / \mathrm{d}) \text { for } \\
14 \text { days } \\
\text { level of evidence = grade Ia }\end{array}$} & \multicolumn{2}{|c|}{$\begin{array}{c}\text { Ceftriaxone }(2 \mathrm{~g} / \mathrm{d}) \text { or Cefotaxime }(2 \mathrm{~g} \times 3 / \mathrm{d}) \text { or } \\
\text { Penicillin } \mathrm{G}(5 \mathrm{MU} / \mathrm{d}) \text { or Doxycycline }(100 \mathrm{mg} \times 2 / \mathrm{d} \\
\text { or } 100 \mathrm{mg} \times 3 / \mathrm{d} \text { or } 200-300 \mathrm{mg} / \mathrm{d}) \text { for } 14-21 \text { days } \\
\text { level of evidence }=\text { grade Ia to grade III }\end{array}$} & NA & NA \\
\hline $\begin{array}{l}\text { French scientific } \\
\text { societies [7] }\end{array}$ & $\begin{array}{c}\text { Doxycycline }(100 \mathrm{mg} \times \\
2 / \mathrm{d}) \\
\text { for } 14 \text { days } \\
\text { level of evidence }= \\
\text { grade EA }\end{array}$ & $\begin{array}{c}\text { Ceftriaxone }(2 \mathrm{~g} / \mathrm{d}) \text { for } \\
14 \text { days } \\
\text { level of evidence }= \\
\text { grade EA }\end{array}$ & $\begin{array}{l}\text { PNS: Doxycycline }(100 \\
\text { mg } \times 2 / \mathrm{d}) \text { for } 21 \text { days } \\
\mathrm{CNS}: \text { Doxycycline }(200 \\
\mathrm{mg} \times 2 / \mathrm{d}) \text { for } 21 \text { days } \\
\text { level of evidence }= \\
\text { grade EA }\end{array}$ & $\begin{array}{l}\text { Ceftriaxone }(2 \mathrm{~g} / \mathrm{d}) \text { for } \\
21 \text { days } \\
\text { level of evidence = } \\
\text { grade EA }\end{array}$ & $\begin{array}{c}\text { Doxycycline }(200 \mathrm{mg} / \mathrm{d}) \\
\text { for } 28 \text { days } \\
\text { level of evidence }=\text { grade } \\
\text { EA }\end{array}$ & $\begin{array}{l}\text { If failure: Ceftriaxone } \\
(2 \mathrm{~g} / \mathrm{d}) \text { for } 28 \text { days } \\
\text { level of evidence = grade } \\
\text { EA }\end{array}$ \\
\hline Canada [21] & NA & NA & NA & NA & NA & NA \\
\hline
\end{tabular}


Table 4. Cont.

\begin{tabular}{|c|c|c|c|c|c|c|}
\hline \multirow[t]{2}{*}{ Guidelines } & \multicolumn{2}{|c|}{ Early Lyme Neuroborreliosis } & \multicolumn{2}{|c|}{ Late Lyme Neuroborreliosis } & \multicolumn{2}{|c|}{$\begin{array}{c}\text { Early (<6 Months) and Late ( }>6 \text { Months) } \\
\text { Lyme Arthritis }\end{array}$} \\
\hline & First Intention & Second Intention & First Intention & Second Intention & First Intention & Second Intention \\
\hline IDSA [19] & $\begin{array}{c}\text { Meningitidis or } \\
\text { radiculitis: } \\
\text { Doxycycline }(100 \mathrm{mg} \times \\
2 / \mathrm{d} \text { or } 200 \mathrm{mg} / \mathrm{d}) \text { or } \\
\text { Ceftriaxone }(2 \mathrm{~g} / \mathrm{d}) \text { for } \\
14-21 \text { days } \\
\text { Cranial nerve palsy: } \\
\text { Doxycycline }(100 \mathrm{mg} \times \\
2 / \mathrm{d} \text { or } 200 \mathrm{mg} / \mathrm{d}) \\
\text { for } 14-21 \text { days } \\
\text { Parenchymal } \\
\text { involvement of the brain } \\
\text { or spinal cord: } \\
\text { Ceftriaxone }(2 \mathrm{~g} / \mathrm{d}) \text { or } \\
\text { Cefotaxime }(2 \mathrm{~g} \times 3 / \mathrm{d}) \\
\text { or Penicillin } \mathrm{G}(18-24 \\
\text { MU) for } 14-21 \text { days } \\
\text { level of evidence }= \\
\text { strong recommendation } \\
\text { moderate-quality } \\
\text { evidence }\end{array}$ & $\begin{array}{c} \\
\\
\text { Meningitidis or } \\
\text { radiculitis: } \\
\text { Cefotaxime }(2 \mathrm{~g} \times 3 / \mathrm{d}) \\
\text { or Penicillin } \mathrm{G}(18-24 \\
\text { MU) } \\
\text { for } 14-21 \text { days } \\
\text { level of evidence = } \\
\text { strong recommendation } \\
\text { moderate-quality } \\
\text { evidence }\end{array}$ & NA & NA & $\begin{array}{c}\text { Doxycycline }(200 \mathrm{mg} / \mathrm{d} \text { or } \\
100 \mathrm{mg} \times 2 / \mathrm{d}) \text { or } \\
\text { Amoxicillin }(500 \mathrm{mg} \times \\
3 / \mathrm{d}) \text { or Cefuroxim axetil } \\
(500 \mathrm{mg} \times 2 / \mathrm{d}) \\
\text { for } 28 \text { days } \\
\text { level of evidence }=\text { strong } \\
\text { recommendation } \\
\text { moderate-quality } \\
\text { evidence }\end{array}$ & $\begin{array}{l}\text { If partial response (mild } \\
\text { residual joint swelling): no } \\
\text { antibiotic, search for } \\
\text { differential diagnosis, and } \\
\text { then eventually discuss a } \\
\text { 2nd line of oral antibiotics } \\
\text { level of evidence = strong } \\
\text { recommendation } \\
\text { moderate-quality } \\
\text { evidence }\end{array}$ \\
\hline
\end{tabular}

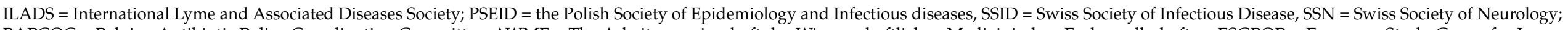

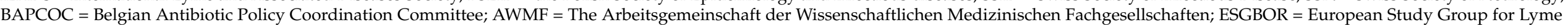

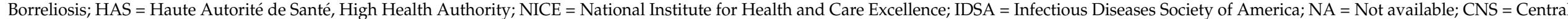
Nervous System; PNS = Peripheral Nervous System; EA = Expert Agreement. 


\subsubsection{Treatment of Other Manifestations (cf. Table 5) \\ LB Carditis (LC)}

Lyme carditis is a rare manifestation of early disseminated infection with B. burgdorferi $(0.3 \%$ to $5 \%$ of clinical manifestations) $[7,19,20]$. Thus, data regarding treatment are rare or nonexistent, and recommendations are based on an extrapolation of the treatment of other manifestations of LB (weak recommendation, low-quality evidence, grade AE) $[7,19,23]$.

The most typical presentation is varying degrees of atrioventricular block (AVB) (first, second or third degree) [7,18-20]. Other conduction system abnormalities may be seen as well as atrial and ventricular arrhythmias. B. burgdorferi infection may also present as pericarditis, acute myocarditis or pancarditis $[19,22]$.

Among the 12 selected recommendations, 7 dealt with LC [7,18-20,22,23,26] (Table 5). For patients with severe manifestations (complete AVB, advanced forms of partial heart block, including second-degree block or first-degree block with a PR interval of $>0.3 \mathrm{~s}$, syncope, unstable hemodynamic) and/or patients who require hospitalization, guidelines were consistent and recommended ceftriaxone $2 \mathrm{~g} /$ day for 14-21 days (6/7 guidelines) $[7,18,19,22,23,26]$. The two French guidelines, the ESGBOR guidelines and the American guidelines from IDSA proposed a switch to oral antibiotics as soon as clinical improvement is achieved $[7,18,19,22]$. Overall, patients with nonsevere manifestations of LC and/or patients who do not need to be hospitalized may be treated with doxycycline $100 \mathrm{mg} \times 2$ /day or $200 \mathrm{mg} /$ day or amoxicillin $1.5 \times 3 \mathrm{~d} /$ day. Only the Belgium and NICE guidelines did not recommend amoxicillin for LC [23,26]. Outpatients may also be treated with cefuroxime-axetil according to ESGBOR guidelines and the American guidelines from IDSA $[18,19]$. The NICE guidelines proposed ceftriaxone $2 \mathrm{~g} / \mathrm{d}$ as an alternative treatment for these patients [23]. It was recommended to treat patients for a total of 14-21 days $(6 / 7$ guidelines) $[7,18,19,22,23,26]$. The Polish guidelines were less precise and proposed treatment using doxycycline, amoxicillin or ceftriaxone, regardless of cardiac manifestations, for 28-30 days (longer than the other guidelines) with no more explanation [20]. The NICE guidelines advised that azithromycin should not be used to treat people with cardiac abnormalities because of its effect on the QT interval [23].

For pregnant women and children under eight years old, Belgium and French High Health Authority guidelines recommend against using doxycycline (only second and third semesters for French guidelines) whereas American guidelines from IDSA indicated increasing favorable information on the safety of short courses of doxycycline in young children, which should impact the risk-to-benefit ratio of using this antibiotic in patients with various manifestations of LB $[19,22,26]$.

\section{Ophthalmological LB (OLB)}

Among the 12 guidelines, only the two French guidelines mentioned the ophthalmological manifestations of $\operatorname{LB}[7,22]$. This is not surprising because they are rare and poorly known. OLB may affect all anatomical structures of the eyes, the most frequent being uveitis and optic neuropathy. Other possible manifestations are early-stage conjunctivitis, keratitis, retinopathy and episcleritis [7,22].

There was no consensual treatment, and an ophthalmologist consultation was essential [22]. However, the two French guidelines recommended the same treatment as for $\mathrm{LNB}$, i.e., ceftriaxone $2 \mathrm{~g} / \mathrm{d}$ for 21 days (first-line treatment, grade $\mathrm{AE}$ ) [7,22]. Because doxycycline has poor intraocular penetration, it is an option only for lesions localized on the surface of the eyes (except for keratitis) for 14 days [7]. Ceftriaxone is the preferred regimen for the treatment of keratitis and intraocular, orbital, or neuro-ophthalmological presentations (grade AE) [7]. Adjuvant corticosteroid therapy may be prescribed in some cases $[7,22]$.

\subsubsection{Management of Post-Treatment Lyme Disease Syndrome (PTLDS) (cf. Table 5)}

Post-treatment Lyme disease syndrome (PTLDS) refers to a pattern of nonspecific symptoms (fatigue, neurocognitive deficits, arthralgia or myalgia) that persist for more 
than six months after a proven and appropriately treated LB and which are caused neither by active nor persistent $B$. burgdorferi infection nor by other diseases $[17,18,26]$. In parallel, the concept of persistent manifestations or symptoms of LB following recommended treatment $[7,19,27]$ or after a possible tick bite [22] was identified in other guidelines without a precise definition.

Ten guidelines detailed the recommendations for ongoing symptoms [7,9-11,14-19]. The Swiss guidelines were exclusively focused on PTLDS and were based on a systematic review of the literature [9]. All the guidelines agreed to retreat in case of proven reinfection from another tick bite and to look for differential diagnoses in case of an absence of improvement after a first line of antibiotics for LB. The NICE guidelines and the French Scientific societies guidelines insisted on the necessity to clearly explain to the patient the possibility of continuing symptoms or sequelae without relation with an active LB, of symptoms of LB that may take months or years to resolve even after treatment and of alternative diagnoses that may explain their symptoms $[7,15]$.

Five randomized, double-blind controlled studies showed that prolonged antibiotic therapy (>3 months) had no sustained benefit or even caused serious adverse effects [9-12]; however, the absence of well-conducted comparative trials to demonstrate the most efficient antibiotic therapy (molecule, dose, duration) for each manifestation of LB may lead to different interpretations and propositions to manage ongoing symptoms.

Seven guidelines (including all those who specifically mentioned PTLDS) did not recommend antibiotic therapy and proposed symptomatic therapy (management of pain, cognitive symptoms, fatigue, etc.) and nonpharmacological approaches (counselling, regular low-impact aerobic exercise programs and cognitive behavioral therapy) [7,9-11,16-18]. The French scientific societies and the IDSA guidelines stated that patients should not receive additional, repeated or prolonged courses of antibiotics for persistent symptoms [7,19], as it is associated with adverse events such as allergic reaction, intravenous catheter complication and diarrhea and the selection of resistant bacteria. Antibiotic retreatment does not appear safe or effective and is discouraged $[7,19]$. Three guidelines suggested a possibility of treatment, after having eliminated all the differential diagnoses, in case of ongoing symptoms $[14,15,19]$. ILADS guidelines recommended oral antibiotics solely or in combination with injectable penicillin $G$ benzathine or ceftriaxone alone or in combination with other antibiotics for 4-6 weeks for persistent symptoms after a tick bite or after a first line of antibiotics for LB [19]. They were the only ones to advocate for a prolonged antibiotic treatment based on an expert agreement with no scientific rationale [27]. The French High Health Authority suggested doxycycline for 28 days for persistent symptoms after a tick bite or after a first line of antibiotics for LB [14]. The NICE guidelines suggested a second line with another molecule in case of ongoing symptoms after a first line of antibiotics for LB [15]. 


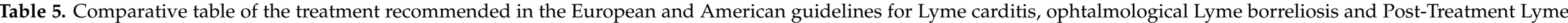
Disease Syndrome.

\begin{tabular}{|c|c|c|c|c|}
\hline \multirow{2}{*}{ Guidelines } & Lyme Carditis & \multicolumn{2}{|c|}{ Ophtalmological Lyme Borreliosis } & Post-Treatment Lyme Disease Syndrome \\
\hline & Second Intention & First Intention & Second Intention & Second Intention \\
\hline ILADS [27] & NA & NA & NA & $\begin{array}{c}\text { If persistent symptoms, treatment options are extensive } \\
\text { and choices must be individualized: oral antibiotics } \\
\text { alone or in combination or injectable penicillin G } \\
\text { benzathine or ceftriaxone alone or in combination with } \\
\text { other antibiotics for 4-6 weeks } \\
\text { level of evidence = low }\end{array}$ \\
\hline PSEID [20] & $\begin{array}{c}\text { Doxycycline }(100 \mathrm{mg} \times 2 / \mathrm{d}) \text { or Amoxicillin } \\
(1.5-2 \mathrm{~g} / \mathrm{d}) \text { or } \\
\text { Ceftriaxone }(2 \mathrm{~g} / \mathrm{d}) \text { for } 28-30 \text { days } \\
\text { level of evidence }=\text { NA }\end{array}$ & NA & NA & NA \\
\hline SSID and SSN [17] & NA & NA & NA & $\begin{array}{l}\text { Antibiotic retreatment is not recommended after } \\
\text { appropriate initial antibiotics for LB. No evidence for } \\
\text { specific treatment. } \\
\text { level of evidence }=\text { strong }\end{array}$ \\
\hline BAPCOC [26] & $\begin{array}{c}\text { Doxycycline }(100 \mathrm{mg} \times 2 / \mathrm{d}) \text { for } 21 \text { days } \\
\text { Or Ceftriaxone }(2 \mathrm{~g} / \mathrm{d}) \text { for } 14 \text { days } \\
(\text { preferred in more severe cases }) \\
\text { level of evidence }=\text { NA }\end{array}$ & NA & NA & $\begin{array}{l}\text { Antibiotic therapy is not recommended } \\
\text { level of evidence }=\text { NA }\end{array}$ \\
\hline AWMF [24] & NA & NA & NA & $\begin{array}{l}\text { Benefit of repeated and long-term antibiotics not verified. } \\
\text { Level of evidence = NA }\end{array}$ \\
\hline ESGBOR [18] & $\begin{array}{c}\text { Outpatients: Doxycycline or Amoxicillin or } \\
\text { Cefuroxime-axetil } \\
\text { Hospitalized patients: Ceftriaxone } \\
\text { for } 14-21 \text { days } \\
\text { A switch to oral antibiotic can be made if } \\
\text { improvement } \\
\text { level of evidence }=\text { NA }\end{array}$ & NA & NA & $\begin{array}{l}\text { Antibiotic therapy is not recommended } \\
\text { level of evidence }=\text { NA }\end{array}$ \\
\hline
\end{tabular}


Table 5. Cont.

\begin{tabular}{|c|c|c|c|c|c|c|}
\hline \multirow{2}{*}{ Guidelines } & \multicolumn{2}{|c|}{ Lyme Carditis } & \multicolumn{2}{|c|}{ Ophtalmological Lyme Borreliosis } & \multicolumn{2}{|c|}{ Post-Treatment Lyme Disease Syndrome } \\
\hline & First Intention & Second Intention & First Intention & Second Intention & First Intention & Second Intention \\
\hline HAS [22] & $\begin{array}{r}\text { Outpatients: Doxycycline } \\
(3 \\
\text { Hospitalized patien } \\
\text { with a switch as soon as } \\
\text { for } 2 \\
\text { level of ev }\end{array}$ & $\begin{array}{l}200 \mathrm{mg} / \mathrm{d}) \text { or Amoxicillin } \\
\text { d) } \\
\text { Ceftriaxone }(2 \mathrm{~g} / \mathrm{d}) \\
\text { ossible to oral antibiotics } \\
\text { days } \\
\text { ence = NA }\end{array}$ & \multicolumn{2}{|c|}{$\begin{array}{c}\text { Ceftriaxone }(2 \mathrm{~g} / \mathrm{d} \text { or } 100 \mathrm{mg} / \mathrm{kg} / \mathrm{d}) \\
\text { for } 28 \text { days } \\
\text { level of evidence }=\text { NA }\end{array}$} & $\begin{array}{c}\text { After having eliminated } \\
\text { differential diagnosis to } \\
\text { LB, consider: } \\
\text { Doxycycline }(200 \mathrm{mg} / \mathrm{d}) \\
\text { for } 28 \text { days } \\
\text { level of evidence = NA }\end{array}$ & $\begin{array}{c}\text { If allergy to doxycycline: } \\
\text { Azithromycin }(1 \mathrm{~g} \text { on D1, } \\
\text { then then } 500 \mathrm{mg} / \mathrm{d}) \text { for } \\
15 \text { days. } \\
\text { level of evidence = NA }\end{array}$ \\
\hline AWMF [25] & NA & NA & NA & NA & \multicolumn{2}{|c|}{$\begin{array}{l}\text { Patients should not be treated with antibiotics. } \\
\text { level of evidence }=\text { NA }\end{array}$} \\
\hline $\begin{array}{l}\text { French scientific } \\
\text { societies [7] }\end{array}$ & $\begin{array}{r}\text { Patient with syncope, typ } \\
>30 \mathrm{~ms} \text { : Ceftriaxone }(2 \\
\text { antibiotics as soon as con } \\
\text { is no long } \\
\text { Patients with ot } \\
\text { Doxycycline }(100 \mathrm{mg} \\
(1 \mathrm{~g} \\
\text { for a tota } \\
\text { level of evidenc }\end{array}$ & $\begin{array}{l}2 \text { or } 3 \text { AVB, or type } 1 \text { AVB } \\
\text { (d) with a switch to oral } \\
\text { nuous cardiac monitoring } \\
\text { required } \\
\text { r manifestations: } \\
2 / \mathrm{d} \text { ) or Amoxicillin } \\
3 / \text { d) } \\
\text { f } 21 \text { days } \\
=\text { grade } C \text { to EA }\end{array}$ & $\begin{array}{c}\text { Lesions on the surface of } \\
\text { the eyes: Doxycycline } \\
(200 \mathrm{mg} / \mathrm{d}) \\
\text { or Ceftriaxone }(2 \mathrm{~g} / \mathrm{d}) \\
\text { for } 14 \text { days } \\
\text { Keratitis, intraocular, } \\
\text { orbital, } \\
\text { neuro-ophthalmological } \\
\text { lesions: } \\
\text { Ceftriaxone }(2 \mathrm{~g} / \mathrm{d}) \text { for } \\
21 \text { days } \\
\text { level of evidence = NA }\end{array}$ & $\begin{array}{l}\text { Doxycycline }(100 \mathrm{mg} \times \\
2 / \mathrm{d}) \text { for } 21 \text { days } \\
\text { level of evidence }=\mathbf{N A}\end{array}$ & \multicolumn{2}{|c|}{$\begin{array}{c}\text { Patients should not receive repeated or prolonged } \\
\text { courses of antibiotics. } \\
\text { level of evidence = grade A }\end{array}$} \\
\hline Canada [21] & NA & NA & NA & NA & NA & NA \\
\hline
\end{tabular}


Table 5. Cont.

\begin{tabular}{|c|c|c|c|c|c|}
\hline \multirow{2}{*}{ Guidelines } & Lyme Carditis & \multicolumn{2}{|c|}{ Ophtalmological Lyme Borreliosis } & \multicolumn{2}{|c|}{ Post-Treatment Lyme Disease Syndrome } \\
\hline & Second Intention & First Intention & Second Intention & First Intention & Second Intention \\
\hline IDSA [19] & $\begin{array}{c}\text { Outpatients: Doxycycline }(100 \mathrm{mg} \times 2 / \mathrm{d} \text { or } \\
200 \mathrm{mg} / \mathrm{d}) \\
\text { or Amoxicillin }(500 \mathrm{mg} \times 3 / \mathrm{d}) \text { or Cefuroxime axetil } \\
\quad(500 \mathrm{mg} \times 2 / \mathrm{d}) \\
\text { Hospitalized patients: initially Ceftriaxone }(2 \mathrm{~g} / \mathrm{d}) \\
\text { then switching to oral antibiotics } \\
\text { For a total of } 14-21 \text { days } \\
\text { Level of evidence }=\text { weak recommendation, very } \\
\text { low-quality evidence }\end{array}$ & NA & NA & $\begin{array}{r}\text { Additional antibio } \\
\text { Level of eviden } \\
\text { modera }\end{array}$ & $\begin{array}{l}\text { is not recommended } \\
\text { recommendation, } \\
\text { evidence. }\end{array}$ \\
\hline
\end{tabular}

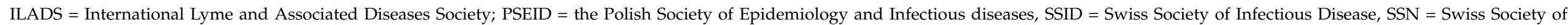

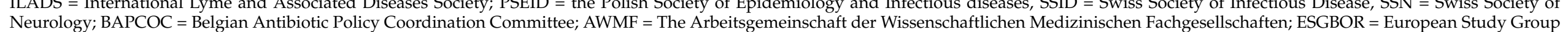

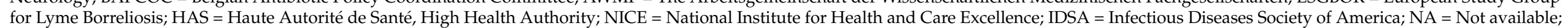
EA = Expert Agreement. 


\section{Materials and Methods}

\subsection{Data Sources and Search Strategy}

We performed a systematic review of guidelines on LB using the PRISMA method [68]. We searched MEDLINE, Google Scholar and databases of the National Institute for Health and Care Excellence (NICE, https:/ / www.nice.org.uk/ accessed on 30 April 2021), The Arbeitsgemeinschaft der Wissenschaftlichen Medizinischen Fachgesellschaften (AWMF, https://www.awmf.org/ accessed on 30 April 2021), Haute Autorité de Santé (HAS, https: / / www.has-sante.fr / accessed on 30 April 2021) and the International Lyme and Associated Diseases Society (ILADS, https: / /www.ilads.org/ accessed on 30 April 2021). We included guidelines from 2014 to 2020, as the majority of the guidelines have been updated recently. Only the most recent guidelines from the same authors or organizations were included in the analysis. Guidelines that only dealt with diagnosis were excluded from the analysis. Language was restricted to French, English, and German. The database search strategy combined the following terms: 'guidelines' or 'recommendations' and "Lyme disease" or "Lyme borreliosis" and "treatment" or "antibiotics" or "antibiotic therapy". The systematic search was independently performed by AR and SN.

\subsection{Assessment of the Quality of the Guidelines}

To assess the methodological quality of each guidelines, the Appraisal of Guidelines for Research and Evaluation II (AGREE II) instrument was used [69] to evaluate 6 domains via 23 items: scope and purpose (domain 1), stakeholder involvement (domain 2), rigor of development (domain 3), clarity of presentation (domain 4), applicability (domain 5) and editorial independence (domain 6). We rated each item on a seven-point scale, with 1 being the lowest rating and 7 being the highest. Two reviewers (AR and SN) independently assessed the quality of each guideline that met the eligibility criteria. If the detailed methodology of the guidelines was accessible in a supplementary document, it was considered during the AGREE II assessment. In the event of disagreement, a third author (JS) was asked to evaluate every item for which the rating differed by more than 1 point, and we achieved consensus through discussion. After consensus meeting, interrater reliability was measured using Cohen's weighted kappa coefficient, and statistical comparisons between scores were performed using two-sided $t$-test. The domain score was calculated as described in AGREE II by the formula: (obtained score-minimum possible score)/(maximum possible score-minimum possible score) $[59,69,70]$.

The maximum possible score was maximum possible score for each item $\times$ number of items in domain $\times$ number of appraisers. The minimum possible score was minimum possible score for each item $\times$ number of items in domain $\times$ number of appraisers. We considered domain scores $<50 \%$ as low quality $[59,69,70]$.

\subsection{Data Extraction of Guidelines and Analysis}

After quality appraisal, AR and SN independently extracted information and checked the data from each guideline. A standard form was designed for data extraction covering the country, publication year, level of scientific evidence, clinical stage of LB and antibiotic therapy (molecule, duration, and dosage). Descriptive analysis of the quality of the guideline included median and interquartile range (IQR). STATA version IC 16 (College Station, TX, USA) was used for all statistical analyses.

No ethical approval or consent was needed for this study.

\section{Conclusions}

European and American guidelines were quite homogeneous regarding the recommended molecules (mostly oral doxycycline as preferential treatment in all situations, and intravenous ceftriaxone as the main alternative), their durations varying from 10 to 28 days and their dosage. The main differences were due to the lack of well-conducted comparative trials, making these guidelines rely on moderate to low level of evidence. A successful treatment was defined in most guidelines by the resolution of the symptoms. In 
case of persistence of symptoms, all the guidelines recommended additional explorations to search the differential diagnoses. The ILADS guidelines were the only ones to suggest longer duration and additional antibiotics for more than 2 months for prolonged symptoms based on an expert consensus. Well-conducted comparative trials such as randomized controlled trials are needed to assess the best molecules, the optimal duration and the most effective doses.

Author Contributions: Conceptualization: A.R. and S.N.; methodology: A.R. and S.N.; validation: A.R.; formal analysis: S.N., A.R., S.P.-D., E.B., J.S., F.S., C.C., C.E., K.B. and P.T.; writing-original draft preparation, A.R., S.N., S.P.-D., E.B., J.S., F.S., C.C., C.E., K.B. and P.T.; writing-review and editing: A.R., S.N., S.P.-D., E.B., J.S., F.S., C.C., C.E., K.B. and P.T.; visualization: A.R., S.N., S.P.-D., E.B., J.S., F.S., C.C., C.E., K.B. and P.T.; supervision: A.R. All authors have read and agreed to the published version of the manuscript.

Funding: This research received no external funding.

Institutional Review Board Statement: Not applicable.

Informed Consent Statement: Not applicable.

Data Availability Statement: All the data of the statistical analysis are available by email at alice.raffetin@chiv.fr or steve.nguala@chiv.fr.

Conflicts of Interest: The authors declare no conflict of interest.

\section{References}

1. GBD. 2017 Disease and Injury Incidence and Prevalence Collaborators. Global, regional, and national incidence, prevalence, and years lived with disability for 354 diseases and injuries for 195 countries and territories, 1990-2017: A systematic analysis for the Global Burden of Disease Study 2017. Lancet 2018, 392, 1789-1858.

2. Schwartz, A.M.; Hinckley, A.F.; Mead, P.S.; Hook, S.A.; Kugeler, K.J. Surveillance for Lyme Disease-United States, $2008-2015$. MMWR Surveill. Summ. 2017, 66, 1-12. [CrossRef] [PubMed]

3. Stanek, G.; Fingerle, V.; Hunfeld, K.-P.; Jaulhac, B.; Kaiser, R.; Krause, A.; Kristoferitsch, W.; O'Connell, S.; Ornstein, K.; Strle, F.; et al. Lyme borreliosis: Clinical case definitions for diagnosis and management in Europe. Clin. Microbiol. Infect. 2011, 17, 69-79. [CrossRef]

4. Figoni, J.; Chirouze, C.; Hansmann, Y.; Lemogne, C.; Hentgen, V.; Saunier, A.; Bouiller, K.; Gehanno, J.F.; Rabaud, C.; Perrot, S.; et al. Lyme borreliosis and other tick-borne diseases. Guidelines from the French Scientific Societies (I): Prevention, epidemiology, diagnosis. Méd. Mal. Infect. 2019, 49, 318-334. [CrossRef]

5. $\quad$ Leeflang, M.M.G.; Ang, C.W.; Berkhout, J.; Bijlmer, H.A.; Van Bortel, W.; Brandenburg, A.H.; Van Burgel, N.D.; Van Dam, A.P.; Dessau, R.B.; Fingerle, V.; et al. The diagnostic accuracy of serological tests for Lyme borreliosis in Europe: A systematic review and meta-analysis. BMC Infect. Dis. 2016, 16, 140. [CrossRef] [PubMed]

6. Eldin, C.; Raffetin, A.; Bouiller, K.; Hansmann, Y.; Roblot, F.; Raoult, D.; Parola, P. Review of European and American guidelines for the diagnosis of Lyme borreliosis. Med. Mal. Infect. 2019, 49, 121-132. [CrossRef] [PubMed]

7. Jaulhac, B.; Saunier, A.; Caumes, E.; Bouiller, K.; Gehanno, J.F.; Rabaud, C.; Perrot, S.; Eldin, C.; De Broucker, T.; Roblot, F.; et al. Lyme borreliosis and other tick-borne diseases. Guidelines from the French scientific societies (II). Biological diagnosis, treatment, persistent symptoms after documented or suspected Lyme borreliosis. Med. Mal. Infect. 2019, 49, 335-346. [CrossRef]

8. Talagrand-Reboul, E.; Raffetin, A.; Zachary, P.; Jaulhac, B.; Eldin, C. Immunoserological Diagnosis of Human Borrelioses: Current Knowledge and Perspectives. Front. Cell Infect. Microbiol. 2020, 10, 241. [CrossRef] [PubMed]

9. Berende, A.; ter Hofstede, H.J.M.; Vos, F.J.; van Middendorp, H.; Vogelaar, M.L.; Tromp, M.; Van den Hoogen, F.H.; Rogier, T.; Donders, A.; Evers, A.W.M.; et al. Randomized Trial of Longer-Term Therapy for Symptoms Attributed to Lyme Disease. N. Engl. J. Med. 2016, 374, 1209-1220. [CrossRef]

10. Klempner, M.S.; Hu, L.T.; Evans, J.; Schmid, C.H.; Johnson, G.M.; Trevino, R.P.; Norton, D.; Levy, L.; Wall, D.; McCall, J.; et al. Two controlled trials of antibiotic treatment in patients with persistent symptoms and a history of Lyme disease. N. Engl. J. Med. 2001, 345, 85-92. [CrossRef]

11. Krupp, L.B.; Hyman, L.G.; Grimson, R.; Coyle, P.K.; Melville, P.; Ahnn, S.; Dattwyler, R.; Chandler, B. Study and treatment of post Lyme disease (STOP-LD): A randomized double masked clinical trial. Neurology 2003, 60, 1923-1930. [CrossRef]

12. Kaplan, R.F.; Trevino, R.P.; Johnson, G.M.; Levy, L.; Dornbush, R.; Hu, L.T.; Evans, J.; Weinstein, A.; Schmid, C.H.; Klempner, M.S Cognitive function in post-treatment Lyme disease: Do additional antibiotics help? Neurology 2003, 60, 1916-1922. [CrossRef]

13. Fallon, B.A.; Keilp, J.G.; Corbera, K.M.; Petkova, E.; Britton, C.B.; Dwyer, E.; Slavov, I.; Cheng, J.; Dobkin, J.; Nelson, D.R.; et al. A randomized, placebo-controlled trial of repeated IV antibiotic therapy for Lyme encephalopathy. Neurology 2008, 70, 992-1003. [CrossRef] 
14. Ates, L.; Hanssen-Hübner, C.; Norris, D.E.; Richter, D.; Kraiczy, P.; Hunfeld, K.-P. Comparison of in vitro activities of tigecycline, doxycycline, and tetracycline against the spirochete Borrelia burgdorferi. Ticks Tick Borne Dis. 2010, 1, 30-34. [CrossRef]

15. Ružić-Sabljić, E.; Podreka, T.; Maraspin, V.; Strle, F. Susceptibility of Borrelia afzelii strains to antimicrobial agents. Int. J. Antimicrob. Agents 2005, 25, 474-478. [CrossRef]

16. Veinović, G.; Cerar, T.; Strle, F.; Lotrič-Furlan, S.; Maraspin, V.; Cimperman, J.; Ružić-Sabljić, E. In vitro susceptibility of European human Borrelia burgdorferi sensu stricto strains to antimicrobial agents. Int. J. Antimicrob. Agents 2013, 41, 288-291. [CrossRef]

17. Nemeth, J.; Bernasconi, E.; Heininger, U.; Abbas, M.; Nadal, D.; Strahm, C.; Erb, S.; Zimmerli, S.; Furrer, H.; Delaloye, J.; et al. Update of the Swiss guidelines on post-treatment Lyme disease syndrome. Swiss Med Wkly. 2016, 146, w14353. [PubMed]

18. Steere, A.C.; Strle, F.; Wormser, G.P.; Hu, L.T.; Branda, J.A.; Hovius, J.W.R.; Li, X.; Mead, P.S. Lyme borreliosis. Nat. Rev. Dis. Primers 2016, 2, 16090. [CrossRef] [PubMed]

19. Lantos, P.M.; Rumbaugh, J.; Bockenstedt, L.K.; Falck-Ytter, Y.T.; Aguero-Rosenfeld, M.E.; Auwaerter, P.G.; Baldwin, K.; Bannuru, R.R.; Belani, K.K.; Bowie, W.R.; et al. Clinical Practice Guidelines by the Infectious Diseases Society of America, American Academy of Neurology, and American College of Rheumatology: 2020 Guidelines for the Prevention, Diagnosis, and Treatment of Lyme Disease. Neurology 2021, 96, 262-273.

20. Pancewicz, S.A.; Garlicki, A.M.; Moniuszko-Malinowska, A.; Zajkowska, J.; Kondrusik, M.; Grygorczuk, S.; Czupryna, P.; Duna, J. Diagnosis and treatment of tick-borne diseases recommendations of the Polish Society of Epidemiology and Infectious Diseases. Przegl. Epidemiol. 2015, 69, 309-316. [PubMed]

21. Island, P.E. Guidelines for the Management and Control of Lyme Disease; Chief Public Health Office: Charlottetown, PE, Canada, 2019.

22. Borréliose de Lyme et Autres Maladies Vectorielles à Tiques (MVT). 2018, pp. 1-26. Available online: https:/ /www.has-sante.fr/ upload/docs/application/pdf/2018-06/reco266_rbp_borreliose_de_lyme_cd_2018_06_13_recommandations.pdf (accessed on 30 April 2021).

23. Lyme Disease. Available online: https://www.nice.org.uk/guidance/ng95/resources/lyme-disease-pdf-1837756839877 (accessed on 30 April 2021).

24. Hofmann, H.; Fingerle, V.; Hunfeld, K.-P.; Huppertz, H.-I.; Krause, A.; Rauer, S.; Ruf, B.; Consensus Group. Cutaneous Lyme borreliosis: Guideline of the German Dermatology Society. GMS Ger. Med. Sci. 2017, 15. [CrossRef]

25. Rauer, S.; Kastenbauer, S.; Fingerle, V.; Hunfeld, K.-P.; Huppertz, H.-I.; Dersch, R. Lyme Neuroborreliosis. Dtsch. Arztebl. Int. 2018, 115, 751-756. [CrossRef] [PubMed]

26. Belkhir, L.; Delaere, B.; De Loof, G.; De Munter, P.; Frippiat, F.; Jacobs, F. Borréliose de Lyme (Infection à Borrelia); The Belgian Antibiotic Policy Coordination Committee: Brussels, Belgium, 2016; p. 28.

27. Cameron, D.J.; Johnson, L.B.; Maloney, E.L. Evidence assessments and guideline recommendations in Lyme disease: The clinical management of known tick bites, erythema migrans rashes and persistent disease. Expert Rev. Anti-Infect. Ther. 2014, 12, 1103-1135. [CrossRef]

28. Barsic, B.; Maretic, T.; Majerus, L.; Strugar, J. Comparison of azithromycin and doxycycline in the treatment of erythema migrans. Infection 2000, 28, 153-156. [CrossRef] [PubMed]

29. Cerar, D.; Cerar, T.; Ruzić-Sabljić, E.; Wormser, G.P.; Strle, F. Subjective symptoms after treatment of early Lyme disease. Am. J. Med. 2010, 123, 79-86. [CrossRef] [PubMed]

30. Nadelman, R.B.; Luger, S.W.; Frank, E.; Wisniewski, M.; Collins, J.J.; Wormser, G.P. Comparison of cefuroxime axetil and doxycycline in the treatment of early Lyme disease. Ann. Intern. Med. 1992, 117, 273-280. [CrossRef] [PubMed]

31. Eliassen, K.E.; Reiso, H.; Berild, D.; Lindbæk, M. Comparison of phenoxymethylpenicillin, amoxicillin, and doxycycline for erythema migrans in general practice. A randomized controlled trial with a 1-year follow-up. Clin. Microbiol. Infect. 2018, 24, 1290-1296. [CrossRef]

32. Luft, B.J.; Dattwyler, R.J.; Johnson, R.C.; Luger, S.W.; Bosler, E.M.; Rahn, D.W.; Masters, E.J.; Grunwaldt, E.; Gadgil, S.D. Azithromycin compared with amoxicillin in the treatment of erythema migrans. A double-blind, randomized, controlled trial. Ann. Intern. Med. 1996, 124, 785-791. [CrossRef] [PubMed]

33. Eppes, S.C.; Childs, J.A. Comparative study of cefuroxime axetil versus amoxicillin in children with early Lyme disease. Pediatrics 2002, 109, 1173-1177. [CrossRef] [PubMed]

34. Stupica, D.; Maraspin, V.; Bogovic, P.; Ogrinc, K.; Blagus, R.; Cerar, T.; Strle, F. Comparison of Clinical Course and Treatment Outcome for Patients with Early Disseminated or Early Localized Lyme Borreliosis. JAMA Dermatol. 2018, 154, $1050-1056$. [CrossRef]

35. Strle, F.; Preac-Mursic, V.; Cimperman, J.; Ruzic, E.; Maraspin, V.; Jereb, M. Azithromycin versus doxycycline for treatment of erythema migrans: Clinical and microbiological findings. Infection 1993, 21, 83-88. [CrossRef] [PubMed]

36. Massarotti, E.M.; Luger, S.W.; Rahn, D.W.; Messner, R.P.; Wong, J.B.; Johnson, R.C.; Steere, A.C. Treatment of early Lyme disease. Am. J. Med. 1992, 92, 396-403. [CrossRef]

37. Wormser, G.P.; Ramanathan, R.; Nowakowski, J.; McKenna, D.; Holmgren, D.; Visintainer, P.; Dornbush, R.; Singh, B.; Nadelman, R.B. Duration of antibiotic therapy for early Lyme disease. A randomized, double-blind, placebo-controlled trial. Ann. Intern. Med. 2003, 138, 697-704. [CrossRef] [PubMed]

38. Weber, K.; Preac-Mursic, V.; Neubert, U.; Thurmayr, R.; Herzer, P.; Wilske, B.; Schierz, G.; Marget, W. Antibiotic therapy of early European Lyme borreliosis and acrodermatitis chronica atrophicans. Ann. N. Y. Acad. Sci. 1988, 539, 324-345. [CrossRef] [PubMed] 
39. Moniuszko, A.; Czupryna, P.; Pancewicz, S.; Kondrusik, M.; Penza, P.; Zajkowska, J. Borrelial lymphocytoma-A case report of a pregnant woman. Ticks Tick Borne Dis. 2012, 3, 257-258. [CrossRef]

40. Aberer, E.; Breier, F.; Stanek, G.; Schmidt, B. Success and failure in the treatment of acrodermatitis chronica atrophicans. Infection 1996, 24, 85-87. [CrossRef] [PubMed]

41. Kindstrand, E.; Nilsson, B.Y.; Hovmark, A.; Pirskanen, R.; Asbrink, E. Peripheral neuropathy in acrodermatitis chronica atrophicans-Effect of treatment. Acta Neurol. Scand. 2002, 106, 253-257. [CrossRef]

42. Lenormand, C.; Jaulhac, B.; Debarbieux, S.; Dupin, N.; Granel-Brocard, F.; Adamski, H.; Barthel, C.; Cribier, B.; Lipsker, D. Expanding the clinicopathological spectrum of late cutaneous Lyme borreliosis (acrodermatitis chronica atrophicans [ACA]): A prospective study of 20 culture- and/or polymerase chain reaction (PCR)-documented cases. J. Am. Acad. Dermatol. 2016, 74, 685-692. [CrossRef]

43. Asbrink, E.; Olsson, I.; Hovmark, A. Erythema chronicum migrans Afzelius in Sweden. A study on 231 patients. Zent. Bakteriol. Mikrobiol. Hyg. Ser. A 1986, 263, 229-236. [CrossRef]

44. Asbrink, E.; Hovmark, A. Lyme borreliosis. Clin Dermatol. 1993, 11, 329-330.

45. Dychter, S.S.; Gold, D.A.; Carson, D.; Haller, M. Intravenous therapy: A review of complications and economic considerations of peripheral access. J. Infus. Nurs. 2012, 35, 84-91. [CrossRef]

46. Dotevall, L.; Hagberg, L. Penetration of doxycycline into cerebrospinal fluid in patients treated for suspected Lyme neuroborreliosis. Antimicrob. Agents Chemother. 1989, 33, 1078-1080. [CrossRef] [PubMed]

47. Karlsson, M.; Hammers, S.; Nilsson-Ehle, I.; Malmborg, A.S.; Wretlind, B. Concentrations of doxycycline and penicillin G in sera and cerebrospinal fluid of patients treated for neuroborreliosis. Antimicrob. Agents Chemother. 1996, 40, 1104-1107. [CrossRef]

48. Sicklinger, M.; Wienecke, R.; Neubert, U. In vitro susceptibility testing of four antibiotics against Borrelia burgdorferi: A comparison of results for the three genospecies Borrelia afzelii, Borrelia garinii, and Borrelia burgdorferi sensu stricto. J. Clin. Microbiol. 2003, 41, 1791-1793. [CrossRef]

49. Dattwyler, R.J.; Luft, B.J.; Kunkel, M.J.; Finkel, M.F.; Wormser, G.P.; Rush, T.J.; Grunwaldt, E.; Agger, W.A.; Franklin, M.; Oswald, D.; et al. Ceftriaxone compared with doxycycline for the treatment of acute disseminated Lyme disease. N. Engl. J. Med. 1997, 337, 289-294. [CrossRef] [PubMed]

50. Ljøstad, U.; Skogvoll, E.; Eikeland, R.; Midgard, R.; Skarpaas, T.; Berg, A.; Mygland, A. Oral doxycycline versus intravenous ceftriaxone for European Lyme neuroborreliosis: A multicentre, non-inferiority, double-blind, randomised trial. Lancet Neurol. 2008, 7, 690-695. [CrossRef]

51. Borg, R.; Dotevall, L.; Hagberg, L.; Maraspin, V.; Lotric-Furlan, S.; Cimperman, J.; Strle, F. Intravenous ceftriaxone compared with oral doxycycline for the treatment of Lyme neuroborreliosis. Scand. J. Infect. Dis. 2005, 37, 449-454. [CrossRef] [PubMed]

52. Kohlhepp, W.; Oschmann, P.; Mertens, H.G. Treatment of Lyme borreliosis. Randomized comparison of doxycycline and penicillin G. J. Neurol. 1989, 236, 464-469. [CrossRef] [PubMed]

53. Karlsson, M.; Hammers-Berggren, S.; Lindquist, L.; Stiernstedt, G.; Svenungsson, B. Comparison of intravenous penicillin G and oral doxycycline for treatment of Lyme neuroborreliosis. Neurology 1994, 44, 1203. [CrossRef]

54. Ljøstad, U.; Henriksen, T.-H. Management of neuroborreliosis in European adult patients. Acta Neurol. Scand. Suppl. 2008, 188, 22-28. [CrossRef] [PubMed]

55. Pfister, H.W.; Preac-Mursic, V.; Wilske, B.; Einhäupl, K.M. Cefotaxime vs penicillin G for acute neurologic manifestations in Lyme borreliosis. A prospective randomized study. Arch. Neurol. 1989, 46, 1190-1194. [CrossRef] [PubMed]

56. Oksi, J.; Nikoskelainen, J.; Hiekkanen, H.; Lauhio, A.; Peltomaa, M.; Pitkäranta, A.; Nyman, D.; Granlund, H.; Carlsson, S.-A.; Seppälä, I.; et al. Duration of antibiotic treatment in disseminated Lyme borreliosis: A double-blind, randomized, placebocontrolled, multicenter clinical study. Eur. J. Clin. Microbiol. Infect. Dis. 2007, 26, 571-581. [CrossRef]

57. Cadavid, D.; Auwaerter, P.G.; Rumbaugh, J.; Gelderblom, H. Antibiotics for the neurological complications of Lyme disease. Cochrane Database Syst. Rev. 2016, 12, 6978. [CrossRef] [PubMed]

58. Kortela, E.; Kanerva, M.J.; Puustinen, J.; Hurme, S.; Airas, L.; Lauhio, A.; Hohenthal, U.; Jalava-Karvinen, P.; Nieminen, T.; Finnilä, T.; et al. Oral Doxycycline Compared to Intravenous Ceftriaxone in the Treatment of Lyme Neuroborreliosis: A Multicenter, Equivalence, Randomized, Open-label Trial. Clin. Infect. Dis. 2021, 72, 1323-1331. [CrossRef] [PubMed]

59. Dersch, R.; Toews, I.; Sommer, H.; Rauer, S.; Meerpohl, J.J. Methodological quality of guidelines for management of Lyme neuroborreliosis. BMC Neurol. 2015, 15, 242. [CrossRef] [PubMed]

60. Steere, A.C.; Green, J.; Schoen, R.T.; Taylor, E.; Hutchinson, G.J.; Rahn, D.W.; Malawista, S.E. Successful parenteral penicillin therapy of established Lyme arthritis. N. Engl. J. Med. 1985, 312, 869-874. [CrossRef] [PubMed]

61. Steere, A.C.; Levin, R.E.; Molloy, P.J.; Kalish, R.A.; Abraham, J.H.; Liu, N.Y.; Schmid, C.H. Treatment of Lyme arthritis. Arthritis Rheum. 1994, 37, 878-888. [CrossRef] [PubMed]

62. Dattwyler, R.J.; Wormser, G.P.; Rush, T.J.; Finkel, M.F.; Schoen, R.T.; Grunwaldt, E.; Franklin, M.; Hilton, E.; Bryant, G.L.; Agger, W.A.; et al. A comparison of two treatment regimens of ceftriaxone in late Lyme disease. Wien. Klin. Wochenschr. 2005, 117, 393-397. [CrossRef] [PubMed]

63. Dattwyler, R.J.; Halperin, J.J.; Volkman, D.J.; Luft, B.J. Treatment of late Lyme borreliosis-randomised comparison of ceftriaxone and penicillin. Lancet 1988, 1, 1191-1194. [CrossRef]

64. Renaud, I.; Cachin, C.; Gerster, J.-C. Good outcomes of Lyme arthritis in 24 patients in an endemic area of Switzerland. Jt. Bone Spine 2004, 71, 39-43. [CrossRef] 
65. Nimmrich, S.; Becker, I.; Horneff, G. Intraarticular corticosteroids in refractory childhood Lyme arthritis. Rheumatol. Int. 2014, 34, 987-994. [CrossRef] [PubMed]

66. Valesová, H.; Mailer, J.; Havlík, J.; Hulínská, D.; Hercogová, J. Long-term results in patients with Lyme arthritis following treatment with ceftriaxone. Infection 1996, 24, 98-102.

67. Tory, H.O.; Zurakowski, D.; Sundel, R.P. Outcomes of children treated for Lyme arthritis: Results of a large pediatric cohort. J Rheumatol. 2010, 37, 1049-1055. [CrossRef] [PubMed]

68. Shamseer, L.; Moher, D.; Clarke, M.; Ghersi, D.; Liberati, A.; Petticrew, M.; Shekelle, P.; Stewart, L.A.; PRISMA-P Group. Preferred reporting items for systematic review and meta-analysis protocols (PRISMA-P) 2015: Elaboration and explanation. BMJ 2015, 349, g7647. [CrossRef] [PubMed]

69. Brouwers, M.C.; Kho, M.E.; Browman, G.P.; Burgers, J.S.; Cluzeau, F.; Feder, G.; Fervers, B.; Graham, I.D.; Grimshaw, J.; Hanna, S.E.; et al. AGREE II: Advancing guideline development, reporting and evaluation in health care. Can. Med. Assoc. J. 2010, 182, E839-E842. [CrossRef] [PubMed]

70. Zhang, M.; Zhou, Y.; Zhong, J.; Wang, K.; Ding, Y.; Li, L.; Pan, X. Quality appraisal of gestational diabetes mellitus guidelines with AGREE II: A systematic review. BMC Pregnancy Childbirth 2019, 19, 478. [CrossRef] [PubMed] 